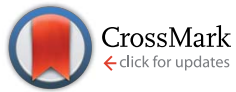

Cite this: RSC Adv., 2015, 5, 37044

Received 30th March 2015

Accepted 9th April 2015

DOI: $10.1039 / c 5 r a 05577 f$

www.rsc.org/advances

\section{Nanotoxicity of polyelectrolyte-functionalized titania nanoparticles towards microalgae and yeast: role of the particle concentration, size and surface charge $\dagger$}

\begin{abstract}
Mohammed J. Al-Awady, Gillian M. Greenway and Vesselin N. Paunov*
We studied the nanotoxicity of titania nanoparticles $\left(\mathrm{TiO}_{2} \mathrm{NPs}\right)$ of various hydrodynamic diameters and crystallite sizes towards C. reinhardtii microalgae and S. cerevisiae (yeast) upon illumination with UV and visible light. The cell viability was assessed for a range of nanoparticle concentrations and incubation times. We found that bare $\mathrm{TiO}_{2} \mathrm{NPs}$ affect the $\mathrm{C}$. reinhardtii cell viability at much lower particle concentrations than for yeast. We observed an increase of the $\mathrm{TiO}_{2} \mathrm{NPs}$ toxicity upon illumination with UV light compared with that in dark conditions due to the oxidative stress of the produced reactive oxygen species. We also found an increased $\mathrm{TiO}_{2} \mathrm{NPs}$ nanotoxicity upon illumination with visible light which indicates that they may also interfere with the microalgae's photosynthetic system leading to decreased chlorophyll content upon exposure to $\mathrm{TiO}_{2} \mathrm{NPs}$. The results indicate that the larger the hydrodynamic diameter of the $\mathrm{TiO}_{2} \mathrm{NPs}$ the lower is their nanotoxicity, with anatase $\mathrm{TiO}_{2} \mathrm{NPs}$ generally being more toxic than rutile $\mathrm{TiO}_{2} \mathrm{NPs}$. We also prepared a range of polyelectrolyte-coated $\mathrm{TiO}_{2} \mathrm{NPs}$ using a layer by-layer method and studied their nanotoxicity towards yeast and microalgae. We found that the toxicity of the coated $\mathrm{TiO}_{2} \mathrm{NPs}$ changes with their surface charge. $\mathrm{TiO}_{2} \mathrm{NPs}$ coated with cationic polyelectrolyte as an outer layer exhibit much higher nanotoxicity than the ones with an outer layer of anionic polyelectrolyte. TEM images of sectioned microalgae and yeast cells exposed to different polyelectrolyte-coated $\mathrm{TiO}_{2} \mathrm{NPs}$ confirmed the formation of a significant build-up of nanoparticles on the cell surface for bare and cationic polyelectrolyte-coated $\mathrm{TiO}_{2} \mathrm{NPs}$. The effect comes from the increased adhesion of cationic nanoparticles to the cell walls. Significantly, coating the $\mathrm{TiO}_{2} \mathrm{NPs}$ with anionic polyelectrolyte as an outer layer led to a reduced adhesion and much lower nanotoxicity due to electrostatic repulsion with the cell walls. This suggest a new way of making cationic $\mathrm{TiO}_{2} \mathrm{NPs}_{\text {safer for }}$ use in different formulations by pre-coating them with anionic polyelectrolytes. The results of this study give important insights into the various factors controlling the nanotoxicity of $\mathrm{TiO}_{2} \mathrm{NPs}$.
\end{abstract}

\section{Introduction}

Over the past decade a range of nanomaterials have been synthesised and explored for new applications and the demand for synthetic nanoparticles has seen a sharp increase. Due to their small particle size and correspondingly large surface area, nanomaterials can display unusual chemical and physical properties that differ substantially from those of bulk materials of the same chemical composition. ${ }^{1,2}$ This can in principle yield a range of technological advantages when nanomaterials are used in consumer products, for example antimicrobial nanocoatings in clothes, washing machines and fridges, waste water

Department of Chemistry, University of Hull, Cottingham Road, Hull HU6 7RX, UK. E-mail: V.N.Paunov@hull.ac.uk; Fax:+44 (o)1482466410; Tel: +44 (0)1482465660

$\dagger$ Electronic supplementary information (ESI) available. See DOI: $10.1039 / \mathrm{c} 5 \mathrm{ra} 05577 \mathrm{f}$ treatments, drug delivery vehicles, cosmetics, sunscreens, nanocomposites and others. It has however, been demonstrated that very small nanoparticles have the ability to penetrate through the cellular membranes of living organisms. ${ }^{2}$ This is one of the reasons for an increasing debate about their potential side effects to human health ${ }^{3,4}$ and the risks related to exposure to nanomaterials and the impacts of their post-use release in the environment. The chemical composition of the nanoparticles has a significant effect on their potential interactions with biological membranes. A range of nanoparticles are known to internalise into cells through endocytosis, potentially leading to inflammation, cell membrane destruction and genotoxicity..$^{5-7}$

Titanium dioxide $\left(\mathrm{TiO}_{2}\right.$, titania) powders are widely used in paints, cosmetics and food colorants products ${ }^{8}$ as well as in catalysis where they act as a photo reactive substance., ${ }^{\mathbf{9} 10}$ Titania has a photocatalytic properties; upon irradiation with photons 
(A)

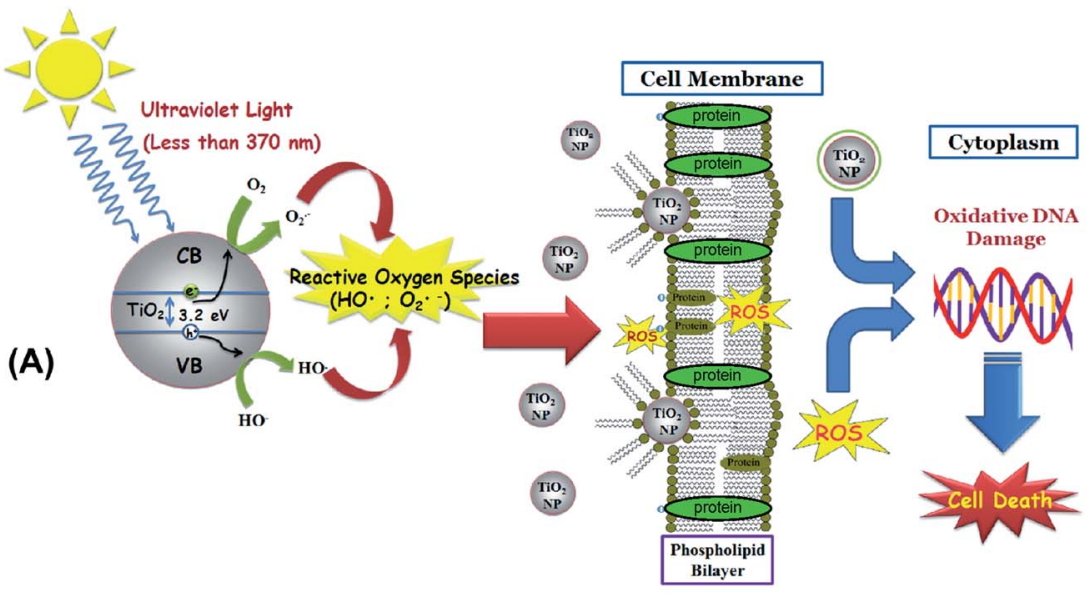

(B)

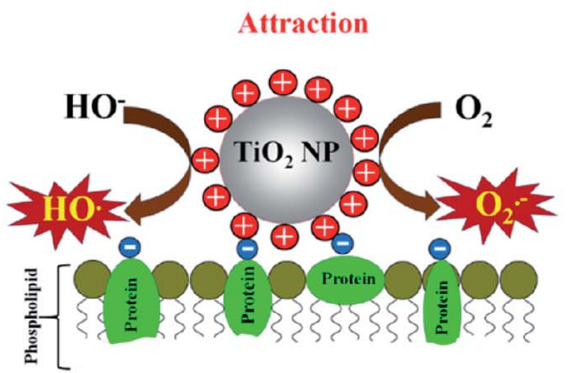

(C)

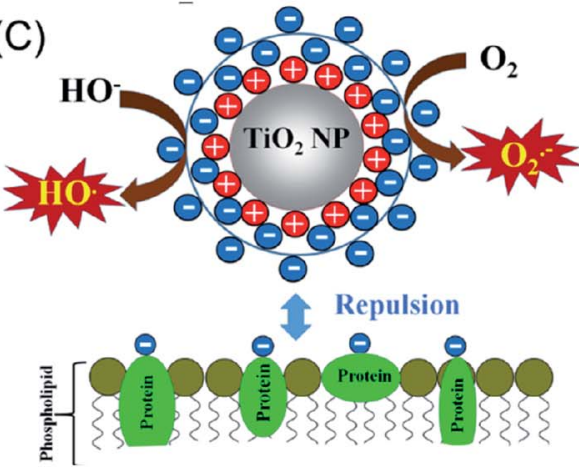

Fig. 1 (A) Mechanism of cytotoxic action of $\mathrm{TiO}_{2} \mathrm{NPs}$ due to the generation of reactive oxygen species (ROS) in presence of sunlight and oxygen which can lead to cell damage. (B) The adhesion of the uncoated $\mathrm{TiO}_{2} \mathrm{NPs}$ to the cell wall surfaces favored due to their opposite surface charges. (C) The interaction between the anionic surface of the cell membrane and $\mathrm{TiO}_{2} \mathrm{NPs}$ coated with anionic polyelectrolyte is repulsive. The cationic $\mathrm{TiO}_{2} \mathrm{NPs}$ and $\mathrm{TiO}_{2} \mathrm{NPs} / \mathrm{PSS} / \mathrm{PAH}$ nanoparticles are expected to be more toxic to the cells than the anionic TiO $2 \mathrm{NPs} / \mathrm{PSS}$ particles.

of energy higher than its band gap (about $3.4 \mathrm{eV}$ for anatase) charge separation occurs with the formation of a hole in the valence band and an electron in the conduction band. This can lead to redox reactions with adsorbed species such as water, hydroxide ions $\left(\mathrm{OH}^{-}\right)$, organic compounds, or oxygen to generate free radicals., ${ }^{911} \mathrm{TiO}_{2}$ particulates have also been utilised as sunscreens as they are able to reflect and scatter the UVA and UVB component of sunlight. Although the average size of the titania particles used in such formulations are primarily in the micrometre range, such polydisperse materials usually contain a certain fraction of nano-sized titania particles. Previous studies have evaluated the toxicological effect of titania nanoparticles $\left(\mathrm{TiO}_{2} \mathrm{NPs}\right)$ on rainbow fish, ${ }^{12} D$. magna ${ }^{13}$ green algae $D$. subspicatus. ${ }^{14}$ It has been discussed that when released in the environment, such nanoparticles can potentially be toxic to aquatic life as they can generate hydroxyl radicals upon exposure to sunlight and oxygen which in turn could damage cell content. ${ }^{15}$

Kim and Lee ${ }^{16}$ have also demonstrated a toxic effect of $\mathrm{TiO}_{2} \mathrm{NPs}$ upon illumination with UV light in the presence of oxygen which generates extracellular reactive oxygen species (ROS) that can damage the cell membranes. Other mechanisms for the toxicological effect of $\mathrm{TiO}_{2} \mathrm{NPs}$ have also been discussed which involve adhesion of $\mathrm{TiO}_{2} \mathrm{NPs}$ to algal cells and physical disruption of their cell membranes. ${ }^{17}$ The impact of $\mathrm{TiO}_{2} \mathrm{NPs}$ on algae and other cells when they are not in their growth phase is still not well understood. At present, it is not clear which of these toxicity pathways are impacting the cell viability and what are the controlling factors. In Fig. 1A we present schematically the possible mechanisms of cell toxicity, which could be due to attachment of $\mathrm{TiO}_{2} \mathrm{NPs}$ on the cell wall leading to local oxidation of the cell membrane phospholipids and DNA damage through the generation of $\mathrm{OH}^{-}, \mathrm{O}_{2}{ }^{-}$, and $\mathrm{H}_{2} \mathrm{O}_{2}$ resulting finally in cell death.

In this paper, we explore the role of the $\mathrm{TiO}_{2} \mathrm{NPs}$ surface charge as this could influence the effective toxicity of the particles because it controls their aggregation upon changes in the local ionic strength and $\mathrm{pH}$, as well as their adhesion to biological membranes. It could also influence the nanoparticle interactions with other biomolecules such as proteins and carbohydrates which can be adsorbed on the particles and form a corona of different surface properties to that of the original nanoparticles. The nanoparticle size is also important for their potential toxicity, as smaller particles have higher mobility to migrate between biological compartments. ${ }^{18}$ We synthesized $\mathrm{TiO}_{2} \mathrm{NPs}$ of various particle sizes via hydrolysis and condensation of a titanium isopropoxide precursor. The zeta potential of the $\mathrm{TiO}_{2} \mathrm{NPs}$ indicated that they have positive surface charge in acidic aqueous media. To study the effects of exposure to different types of $\mathrm{TiO}_{2} \mathrm{NPs}$ and their potential impact on aquatic 
systems upon environmental pollution we used $C$. reinhardtii microalgae cells as a proxy for aquatic microorganisms and baker's yeast ( $S$. cerevisiae) as unicellular fungal microorganisms. The cytotoxicity of $\mathrm{TiO}_{2} \mathrm{NPs}$ was investigated in dark conditions and also in the presence of UV and visible light with various incubation times up to 24 hours. Since the $\mathrm{TiO}_{2} \mathrm{NPs}$ are both cationic and UV-photoactive nanoparticles, they could affect the cell viability through several different ways: (i) the cationic nature of the $\mathrm{TiO}_{2} \mathrm{NPs}$ can make them adsorb and disrupt the cell membrane. (ii) The particles could potentially penetrate through the cell membrane and interfere with vital cell organelles. This means that the $\mathrm{TiO}_{2} \mathrm{NPs}$ could potentially interfere with the photosynthetic system of the microalgae cells and affect their ability to photosynthesise. (iii) The UV/visible light-activated $\mathrm{TiO}_{2} \mathrm{NPs}$ can produce reactive oxygen species which may degrade not only the cell membranes in their vicinity, but also potentially damage the cell interior, organelles and its DNA. We envisage that all these pathways can be interdependent and may occur at the same time upon exposure of the cells to $\mathrm{TiO}_{2} \mathrm{NPs}$ in the presence of oxygen and sunlight which has both UV and visible light components (Fig. 1A).

In this work we examine the effect of: (i) the $\mathrm{TiO}_{2} \mathrm{NPs}$ concentration and (ii) particle size on the cell viability of microalgae and yeast at various exposure times in both dark conditions or in UV or visible light. (iii) Our results reveal that the mechanism of cytotoxicity and the nanoparticle internalisation which turns out to differ between microalgae and yeast. (iv) We have done this study systematically on yeast and microalgae in the absence of growth media which may interfere with the particle surface charge. In most of the literature on nanotoxicity studies on algae, yeast and bacteria, the nanoparticle effects are estimated on the cell growth in a culture media which puts the nanoparticles in contact with the growth media components (e.g. peptones) and complicates the interpretation of the results. (v) An additional novelty of our work is

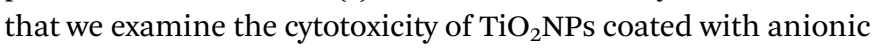
and cationic polyelectrolytes produced using the layer-by-layer method. We examined the effect of the $\mathrm{TiO}_{2} \mathrm{NPs}$ surface coating on the particle toxicity as schematically illustrated in Fig. 1B. (vi) We aim to evaluate the nanotoxicity of multilayercoated $\mathrm{TiO}_{2} \mathrm{NPs}$ on algae and yeast upon UV/vis light illumination and compare the results systematically with those in dark conditions. (vii) We also raise and confirm the hypothesis that coating the $\mathrm{TiO}_{2}$ NPs with anionic polyelectrolytes as an outer layer can lead to reduced nanotoxicity due to their electrostatic repulsion from the cells (Fig. 1C). The latter may have a huge impact on the preparation of potentially safer formulations with nano-sized titania in a range of personal care products.

\section{Experimental}

\section{Materials}

Deionised water produced by Milli-Q reverse osmosis system (Millipore, UK) was used in all experiments. Titanium isopropoxide (TTIP, 97\%) was supplied by Sigma Aldrich, UK. Isopropanol (99\%) was supplied by Merck. Fluorescein diacetate (FDA, 98\%) was purchased from Fluka, UK.
Chlamydomonas reinhardtii (cc-124 strain) was sourced from Flickinger's group at North Caroline State University, USA. This microalgae culture was grown in Tris-Acetate-Phosphate (TAP) culture medium with an incubation temperature of $30{ }^{\circ} \mathrm{C}$. The culture media of $C$. reinhardtii consisted of TAP salts (ammonium chloride, $\mathrm{NH}_{4} \mathrm{Cl}$; magnesium sulphate, $\mathrm{MgSO}_{4} \cdot 7 \mathrm{H}_{2} \mathrm{O}$ and calcium chloride, $\mathrm{CaCl}_{2} \cdot 2 \mathrm{H}_{2} \mathrm{O}$ ), phosphate buffer solution and Hutner's trace elements solution (EDTA disodium salt, $\mathrm{ZnSO}_{4} \cdot 7 \mathrm{H}_{2} \mathrm{O}, \mathrm{H}_{3} \mathrm{BO}_{3}, \mathrm{MnCl}_{2} \cdot 4 \mathrm{H}_{2} \mathrm{O}, \mathrm{CoCl}_{2} \cdot 6 \mathrm{H}_{2} \mathrm{O}, \mathrm{CuSO}_{4} \cdot 5 \mathrm{H}_{2} \mathrm{O}$, $\left.\mathrm{FeSO}_{4} \cdot 7 \mathrm{H}_{2} \mathrm{O},\left(\mathrm{NH}_{4}\right)_{6} \mathrm{Mo}_{7} \mathrm{O}_{24} \cdot 4 \mathrm{H}_{2} \mathrm{O}\right)$, all purchased from SigmaAldrich, UK. We used two different batches of cationic and anionic polyelectrolytes: poly(sodium 4-styrene sulfonate) sodium salt (PSS), average M.W. $\sim 70 \mathrm{kDa}$ and $10 \mathrm{kDa}$, and poly(allylamine hydrochloride) (PAH), average M.W. $15 \mathrm{kDa}$ and $65 \mathrm{kDa}$, respectively, all purchased from Sigma Aldrich, UK. The microalgae batch was grown in the TAP media at $\mathrm{pH} 7$ while being illuminated for 72 hours with a white photo luminescent lamp with a light intensity of $60 \mathrm{~W} \mathrm{~m}^{-2}$ under constant stirring with a magnetic stirrer. ${ }^{19,20}$ Saccharomyces cerevisiae (from Sigma-Aldrich, UK) was cultured as follows. $10 \mathrm{mg}$ of dry (lyophilised) yeast was hydrated in $10 \mathrm{~mL}$ of pre-autoclaved Milli-Q water. Then $1 \mathrm{~mL}$ of the hydrated yeast suspension was added to $100 \mathrm{~mL}$ of the autoclaved YPD culture media (yeast extract, peptone and dextrose) and incubated for 48 hours at $30{ }^{\circ} \mathrm{C} .{ }^{21}$

\section{Methods}

Preparation and characterisation of $\mathrm{TiO}_{2} \mathrm{NPs}$. The hydrolysis reaction of TTIP used for the synthesis of $\mathrm{TiO}_{2} \mathrm{NPs}$ was a modified version of the sol-gel method of Mahshid et al. ${ }^{22}$ which involves two steps: (i) hydrolysis of titanium isopropoxide with excess of aqueous acidic medium ( $\mathrm{pH} 2)$ by using nitric acid as a peptizing agent to convert the produced precipitate to colloid particles of titanium hydroxide. Briefly, $1 \mathrm{M} \mathrm{HNO}_{3}$ was added drop-wise to $250 \mathrm{~mL}$ of Milli-Q water to adjust the $\mathrm{pH}$ to 2 followed by the addition of $15 \mathrm{~mL}$ aliquot of isopropanol. Then, $5.0 \mathrm{~mL}$ of TTIP was added drop-wise to the solution with vigorous stirring which led to formation of a white turbid dispersion due to the TTIP hydrolysis. (ii) The resulted suspension of $\mathrm{Ti}(\mathrm{OH})_{4}$ was heated for 20 hours at $70{ }^{\circ} \mathrm{C}$ to yield titania as a yellow-white precipitate which was filtered, washed with ethanol and further dried under vacuum (Gallenkamp vacuum oven) at $100{ }^{\circ} \mathrm{C}$ for 2 hours. For the preparation of $\mathrm{TiO}_{2}$ NPs of different crystallite size, the titania produced was further annealed at different temperatures ranging from $100{ }^{\circ} \mathrm{C}$ to $800{ }^{\circ} \mathrm{C}$ for 2 hours. We characterised the crystallite sizes of the prepared titania in solid state using Siemens D5000 X-Ray Diffractometer (XRD) with $0.15418 \mathrm{~nm}$ wavelength $(\mathrm{CuK} \alpha$ line). Scherrer's equation ${ }^{23}$ was used to calculate the crystallite size. Transmission electron microscopy (TEM) images of the particle samples were obtained using JEM 2011 (JEOL, Japan) running at $200 \mathrm{kV}$. BET surface area measurements of the titania obtained at different calcination temperatures by nitrogen adsorption at $77 \mathrm{~K}$ were conducted using a Micromeritics instrument (USA). We prepared aqueous dispersions of $\mathrm{TiO}_{2} \mathrm{NPs}$ by dispersing $4 \mathrm{mg}$ of each titania sample in $10 \mathrm{~mL}$ 
aliquots of $20 \mathrm{mM}$ aqueous solution of $\mathrm{NaCl}$ at $\mathrm{pH} 4$ by using a digital sonicator (Branson 450, $5 \mathrm{~mm}$ tip, $400 \mathrm{~W}$ maximal power) at $40 \%$ of the maximum power for 10 minutes at $1 \mathrm{~s} \mathrm{ON} /$ $1 \mathrm{~s}$ OFF pulse time and followed by filtration through a syringe filter of pore size $0.22 \mu \mathrm{m}$. The characterization of the $\mathrm{TiO}_{2} \mathrm{NPs}$ size distribution and zeta potential in aqueous solutions was carried out using a Zetasizer Nano ZL (Malvern, UK). For testing the $\mathrm{pH}$ effect on the particle hydrodynamic diameter and zeta potential the $\mathrm{pH}$ was adjusted from 2 to 9 using $1 \mathrm{M} \mathrm{HCl}$ or $1 \mathrm{M}$ $\mathrm{NaOH}$.

Layer-by-layer polyelectrolyte-coated $\mathrm{TiO}_{2} \mathrm{NPs}$. We prepared polyelectrolyte-coated $\mathrm{TiO}_{2} \mathrm{NPs}$ using only titania synthesised and annealed at $100{ }^{\circ} \mathrm{C}$ (anatase) as described in the previous section. $10 \mathrm{~mL}$ of $1500 \mu \mathrm{g} \mathrm{mL}{ }^{-1} \mathrm{TiO}_{2} \mathrm{NPs}$ dispersion in Milli-Q water was added drop-wise to an equal amount of $10 \mathrm{mg} \mathrm{mL}$ of solution of PSS (M.W. $\sim 70 \mathrm{kDa}$ ) dissolved in $1 \mathrm{mM} \mathrm{NaCl}$ solution. After shaking for 20 minutes, the particles were washed three times by centrifugation for one hour at $8000 \mathrm{rpm}$ to remove the excess of PSS and were finally redispersed in $10 \mathrm{~mL}$ of Milli-Q water. The PSS-coated $\mathrm{TiO}_{2} \mathrm{NPs}$ were then mixed drop-wise with $10 \mathrm{~mL}$ of $10 \mathrm{mg} \mathrm{mL}^{-1}$ PAH (M.W. $15 \mathrm{kDa}$ ) dissolved in $1 \mathrm{mM} \mathrm{NaCl}$ solution, shaken for 20 minutes and centrifuged again three times at $8000 \mathrm{rpm}$ for 1 hour to yield $\mathrm{TiO}_{2} \mathrm{NPs} / \mathrm{PSS} / \mathrm{PAH}$. For further coating with PSS, the latter was mixed drop-wise with $10 \mathrm{~mL}$ of $10 \mathrm{mg} \mathrm{mL}^{-1}$ PSS while sonicated. The mixture was shaken for $20 \mathrm{~min}$, centrifuged and dispersed in Milli-Q water to produce $\mathrm{TiO}_{2} \mathrm{NP} / \mathrm{PSS} / \mathrm{PAH} / \mathrm{PSS}$. Furthermore, we used PSS and PAH of various molar masses (10 kDa and $70 \mathrm{kDa}$ for PSS and $15 \mathrm{kDa}$ and $56 \mathrm{kDa}$ for $\mathrm{PAH}$ ) to examine their effect on the size of the coated $\mathrm{TiO}_{2} \mathrm{NPs}$. After each polyelectrolyte coat, the $\mathrm{TiO}_{2} \mathrm{NPs}$ were characterised by the Zetasizer Nano ZL to check their zeta potential and the particle aggregation.

C. reinhardtii cell viability upon exposure to $\mathrm{TiO}_{2} \mathrm{NPs}$. A $100 \mathrm{~mL}$ aliquot of $5 \times 10^{6}$ cells per $\mathrm{mL}$ C. reinhardtii was centrifuged from the culture media, washed three times and redispersed with $50 \mathrm{~mL}$ Milli-Q water. $5 \mathrm{~mL}$ aliquots of $1 \times 10^{7}$ cells per $\mathrm{mL}$ suspension of the washed $C$. reinhardtii microalgae cells were then incubated with a series of $5 \mathrm{~mL}$ aliquots of aqueous dispersions of $\mathrm{TiO}_{2} \mathrm{NPs}$ of a range of total particle

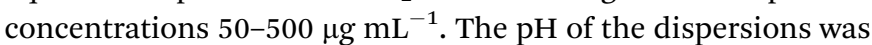
adjusted to 4 and then the samples were split in three parts which were illuminated for fixed periods of 0,2, 4 and 6 hours with UV light or visible light, or kept in dark conditions, respectively. We also treated a control sample of the microalgae under the same conditions without exposure to $\mathrm{TiO}_{2} \mathrm{NPs}$. Then, $1 \mathrm{~mL}$ aliquots of the suspended cells were taken from each treated sample, centrifuged for 4 minutes at $3000 \mathrm{rpm}$ and washed with Milli-Q water to remove the excess of $\mathrm{TiO}_{2} \mathrm{NPs}$. The cells were re-suspended in $1 \mathrm{~mL}$ of Milli-Q water, incubated with one drop of FDA solution in acetone for 10 minutes and then washed three times with Milli-Q water by centrifugation at $4000 \mathrm{rpm}$ for 3 minutes. The cell viability was examined by using Olympus BX51 fluorescence microscope fitted with a DP70 digital camera and FITC fluorescence filter set. The bulk of the cell viability measurements were carried out using an automatic cell counter (A Nexcelom Cellometer Auto X4
Fluorescence) with the fluorescence optics module XB-535-401, excitation $475 \mathrm{~nm} /$ emission $535 \mathrm{~nm}$ (from Bioscience, USA) fitted with Cellometer software to measure the counts of the live and dead cells, as well as the percentage of viable cells in each sample. We used the same procedure to test the effect of polyelectrolyte-coated $\mathrm{TiO}_{2} \mathrm{NPs}$ on the viability of $C$. reinhardtii cells as a proxy for aquatic microorganisms. $C$. reinhardtii cells were incubated with three different concentrations of $\mathrm{TiO}_{2} \mathrm{NPs} /$ PSS $\left(0,100\right.$, and $\left.500 \mu \mathrm{g} \mathrm{mL}^{-1}\right)$ for 6 hours in dark conditions or illuminated with UV light. Analogous experiments were conducted with $\mathrm{TiO}_{2} \mathrm{NPs} / \mathrm{PSS} / \mathrm{PAH}$ and $\mathrm{TiO}_{2} \mathrm{NPs} / \mathrm{PSS} / \mathrm{PAH} / \mathrm{PSS}$ polyelectrolyte coated particles at temperature $31 \pm 2{ }^{\circ} \mathrm{C}$.

Determination of the chlorophyll content of $C$. reinhardtii upon exposure to $\mathrm{TiO}_{2}$ NPs. The protocol used for the determination of the total chlorophyll content of $C$. reinhardtii was adapted from Hartmut. ${ }^{24}$ An aliquot of $2.4 \mathrm{~mL}$ acetone was added to $0.6 \mathrm{~mL}$ of the $C$. reinhardtii samples which had been exposed to $\mathrm{TiO}_{2} \mathrm{NPs}$ at different particle concentration (50$500 \mu \mathrm{g} \mathrm{mL}^{-1}$ ) in the presence of UV or visible light or in dark conditions. The chlorophyll content of the microalgae was extracted for 1 minute by using vortex mixer followed by centrifugation for 5 minutes at $13000 \mathrm{rpm}$. The absorbance of the supernatant was measured at $646 \mathrm{~nm}$ and $663 \mathrm{~nm}$ for the determination of chlorophyll a and chlorophyll b, respectively, by using Perkin-Elmer UV-vis Spectrophotometer, USA (Model Bio Lambda 25) with UV Winlab software.

Yeast cell viability upon exposure to $\mathrm{TiO}_{2} \mathrm{NPs} .20 \mathrm{~mL}$ of the dispersion of baker's yeast cultured in YPD medium was washed by centrifugation with Milli-Q water three times and then redispersed in $40 \mathrm{~mL}$ Milli-Q water. $5 \mathrm{~mL}$ aliquots of this cell dispersion were incubated with $5 \mathrm{~mL} \mathrm{TiO}_{2} \mathrm{NPs}$ aqueous suspension to obtain different total particle concentrations (250, 500, 1000, 2500 and $\left.5000 \mu \mathrm{g} \mathrm{mL} \mathrm{m}^{-1}\right)$. The mixed samples were exposed separately for $0,3,6,12,18$ and 24 hours to visible light or UV light from the top in open glass tubes. The glass tubes were transparent to UV/vis light above $310 \mathrm{~nm}$ (see Fig. S10 in ESI $\dagger$ ). The same experiments were also repeated in dark conditions. For experiments with polyelectrolyte-coated $\mathrm{TiO}_{2} \mathrm{NPs}$, we incubated an aliquot of the yeast cells suspension with $\mathrm{TiO}_{2} \mathrm{NPs}$ coated with PSS (M.W. $10 \mathrm{kDa}$ ) and PAH (M.W. $15 \mathrm{kDa})$ at three particle concentrations $(0,1000$, and $\left.2500 \mu \mathrm{g} \mathrm{mL}{ }^{-1}\right)$. The samples were incubated at different times $(0 \mathrm{~h}, 6 \mathrm{~h}, 12 \mathrm{~h}$ and $24 \mathrm{~h})$ in dark conditions or illuminated with UV light. After each experiment, $1 \mathrm{~mL}$ of each yeast suspension sample was washed, re-suspended in $1 \mathrm{~mL}$ Milli-Q water and incubated with a drop of FDA solution in acetone $\left(0.5 \mathrm{mg} \mathrm{mL} \mathrm{mL}^{-1}\right)$ for 20 minutes. The samples were then washed with Milli-Q water, centrifuged three times at $3000 \mathrm{rpm}$ for 4 minutes and the cell viability was examined by fluorescence microscopy and an automatic cell counter (Nexcelom Cellometer Auto X4 Fluorescence).

TEM images of cells after exposure to $\mathrm{TiO}_{2} \mathrm{NPs}$. The cell morphology of $C$. reinhardtii or yeast cells after 6 hours of incubation with $500 \mathrm{mg} \mathrm{mL}{ }^{-1} \mathrm{TiO}_{2}$ NPs was examined with TEM using the following protocol. The cells studied were centrifuged from the $\mathrm{TiO}_{2}$ NPs suspension at $500 \mathrm{rpm}$, washed with Milli-Q water and fixed in $2 \mathrm{wt} \%$ glutaraldehyde for 1 hour at room 
temperature followed by treatment with $1 \mathrm{wt} \%$ osmium tetraoxide for 1 hour. The cells were then treated for $1 \mathrm{~h}$ with $2.5 \%$ uranyl acetate and washed with solutions of ethanol of increasing concentration. After standard dehydration, the cell were embedded in fresh epoxy/araldite for 48 hours at $60{ }^{\circ} \mathrm{C}$, left at room temperature for 48 hours and sectioned using the ultra-
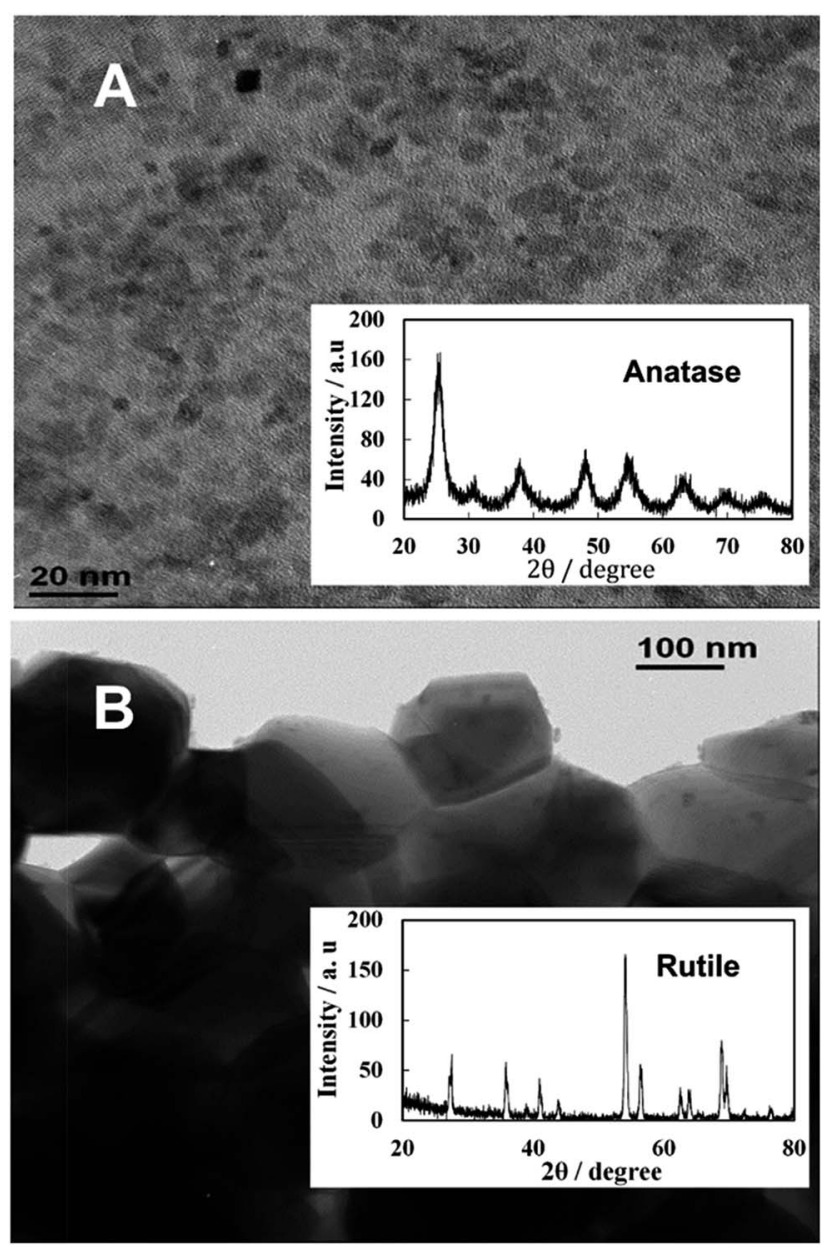

Fig. 2 TEM images and XRD spectra of (A) anatase and (B) rutile $\mathrm{TiO}_{2} \mathrm{NPs}$ prepared by calcination at $200{ }^{\circ} \mathrm{C}$ and $800^{\circ} \mathrm{C}$, respectively. Note the difference in the particle crystallite size and XRD patterns. microtome. The sectioned samples were then imaged with a JEOL 2010 Transmission Electron Microscope (TEM) (Japan) operating at $80 \mathrm{kV}$ and the images were captured with a Gatan US4000 digital camera. A lanthanum hexaboride (LaB6) crystal was used as the electron source.

\section{Results and discussion}

Samples of $\mathrm{TiO}_{2} \mathrm{NPs}$ were prepared at various calcination temperatures as described in the previous section. For the $\mathrm{TiO}_{2}$ NPs prepared by annealing at $100{ }^{\circ} \mathrm{C}$, the titania crystallite size was found to be $5 \mathrm{~nm}$ which agrees with the literature value. ${ }^{23}$ Fig. 2A shows TEM images of the prepared titania samples where the average crystallite domains size agrees with the crystallite size calculated from the XRD data and corresponds to anatase. However, Fig. 2B shows significantly different morphology and particle domain sizes typical for the rutile form of titania obtained after further calcination of the titania sample at $800{ }^{\circ} \mathrm{C}$ which gives a crystallite domain size of $142 \mathrm{~nm}$. Table 1 shows the effect of the annealing temperature on the final crystallite domain size of the titania samples. It can be seen that an increase in the annealing temperature leads to an increase in the crystallite size. The BET surface area decreases from $163 \mathrm{~m}^{2} \mathrm{~g}^{-1}$ for the anatase $\mathrm{TiO}_{2} \mathrm{NPs}$ annealed at $100{ }^{\circ} \mathrm{C}$ to $7.5 \mathrm{~m}^{2} \mathrm{~g}^{-1}$ for $\mathrm{TiO}_{2} \mathrm{NPs}$ annealed at $800{ }^{\circ} \mathrm{C}$. Also, annealing at $800{ }^{\circ} \mathrm{C}$ led to a phase transformation from anatase to the more stable rutile form of $\mathrm{TiO}_{2} \mathrm{NPs} .{ }^{25}$ Further characterisation of the $\mathrm{TiO}_{2} \mathrm{NPs}$ samples was done by UV-vis spectroscopy, thermogravimetric analysis, powder XRD, Fourier Transform Infrared Spectroscopy (FTIR), Energy Dispersive XRay Analysis (EDX) and the results are included in the ESI. $\dagger$

\section{Zeta potential and particle size of $\mathrm{TiO}_{2} \mathrm{NPs}$ in aqueous solutions}

Aqueous dispersions of the titania samples, synthesised at different annealing temperatures were prepared by sonication as described in the previous section and the particle size distribution and the zeta potential were measured as a function of pH. Table 1 also summarizes the average particle hydrodynamic diameters in aqueous solution at $\mathrm{pH} 4$. Note that the average particle size of the $\mathrm{TiO}_{2} \mathrm{NPs}$ when dispersed in an

Table 1 The effect of the annealing temperature during the $\mathrm{TiO}_{2} \mathrm{NPs}$ synthesis on the crystallite domain size and the BET surface area of titania. We also include the hydrodynamic diameters and zeta potential of the $\mathrm{TiO}_{2} \mathrm{NPs}$ after dispersing each sample in $\mathrm{Milli}-\mathrm{Q}$ water at $\mathrm{pH} 4$ by sonication at the same conditions

\begin{tabular}{|c|c|c|c|c|c|}
\hline \multirow[b]{2}{*}{ Calcination temperature $/{ }^{\circ} \mathrm{C}$} & \multicolumn{2}{|c|}{$\begin{array}{l}\text { Average crystallite } \\
\text { size/nm }\end{array}$} & \multirow[b]{2}{*}{ BET surface area $/ \mathrm{m}^{2} \mathrm{~g}^{-1}$} & \multirow[b]{2}{*}{ Hydrodynamic diameter/nm } & \multirow[b]{2}{*}{ Zeta potential/mV } \\
\hline & Anatase & Rutile & & & \\
\hline 100 & 5 & - & 163 & $25 \pm 20$ & $40 \pm 9$ \\
\hline 200 & 6 & - & 152 & $25 \pm 20$ & $36 \pm 10$ \\
\hline 300 & 6.5 & - & 139 & $27 \pm 20$ & $32 \pm 6$ \\
\hline 600 & 28 & 38 & 9 & $50 \pm 25$ & $3 \pm 10$ \\
\hline 800 & - & 142 & 7.5 & $145 \pm 60$ & $-26 \pm 8$ \\
\hline
\end{tabular}


aqueous media is very different from their crystallite domain size in solid state. For example, titania of $5 \mathrm{~nm}$ crystallite domain size in solid state (see Table 1) upon dispersing in MilliQ water gave $\mathrm{TiO}_{2} \mathrm{NPs}$ of an average diameter $25 \mathrm{~nm}$. Fig. S1 from the ESI $\uparrow$ shows a typical size distribution of these $\mathrm{TiO}_{2} \mathrm{NPs}$ after being dispersed in aqueous solution. This indicates that the individual $\mathrm{TiO}_{2} \mathrm{NPs}$ in aqueous solutions are clusters of smaller crystallites rather than single crystallites.

Fig. 3 shows that the zeta potential of the anatase $\mathrm{TiO}_{2} \mathrm{NPs}$ in an aqueous solution decreases gradually from positive at low $\mathrm{pH}$ to negative at high $\mathrm{pH}$, with an isoelectric point at approximately 6.8. We found that above $\mathrm{pH} 5.5$ the particles start to aggregate (Fig. 3) as the particle surface charge and the corresponding electrostatic repulsion are not strong enough to prevent their partial coagulation. However, we were unable to redisperse the aggregated $\mathrm{TiO}_{2} \mathrm{NPs}$ by subsequent lowering the $\mathrm{pH}$ of the aggregated particles dispersion below 5 . This indicates that the $\mathrm{TiO}_{2} \mathrm{NPs}$ aggregation is irreversible, possibly due to covalent bond formation among $\mathrm{TiO}_{2}$ NPs within the aggregates. Fig. S9 (ESI $\dagger$ ) gives the dependence of the average particle diameter and zeta potential as a function of the solution $\mathrm{pH}$ for rutile $\mathrm{TiO}_{2} \mathrm{NPs}$, produced by annealing at $800{ }^{\circ} \mathrm{C}$. One sees that rutile NPs have not only different particle size but also different surface properties from anatase NPs which is reflected in their nanotoxicity.

\section{Toxicity of $\mathrm{TiO}_{2} \mathrm{NPs}$ on $C$. reinhardtii in UV/visible light}

We conducted experiments for the incubation of $C$. reinhardtii with $\mathrm{TiO}_{2}$ NPs whilst being illuminated with visible light, UV light or in dark conditions. The emission spectra of visible light source and the UV light source is given in Fig. S6 and S10, respectively in the ESI. $\uparrow$ Since the $\mathrm{TiO}_{2}$ NPs could also potentially interact with the cell growth media, this can affect the cells two-fold: (i) by depleting their nutrients from the media and (ii) by forming a protein corona around the NPs in solution which changes the way the NPs adhere to the cell membrane. To eliminate the effect of the growth media on the nanoparticles, we used $C$. reinhardtii cultures which have been removed from the growth media and re-dispersed in Milli-Q water. The

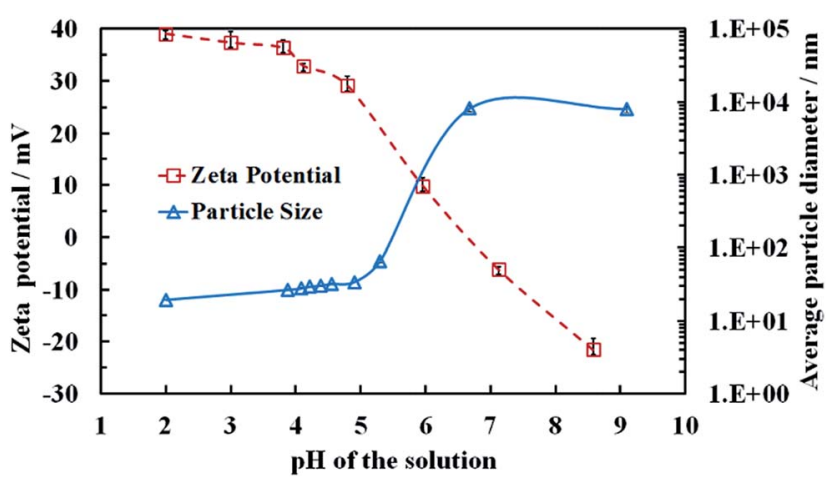

Fig. 3 The variation the zeta potential and the particle diameter of dispersed anatase $\mathrm{TiO}_{2} \mathrm{NPs}$ in an aqueous solution of $20 \mathrm{mM} \mathrm{NaCl}$ as function of $\mathrm{pH}$ adjusted by addition of $1 \mathrm{M} \mathrm{HCl}$ or $1 \mathrm{M} \mathrm{NaOH}$. The triangles show the effect of $\mathrm{pH}$ on the average particle hydrodynamic diameter.
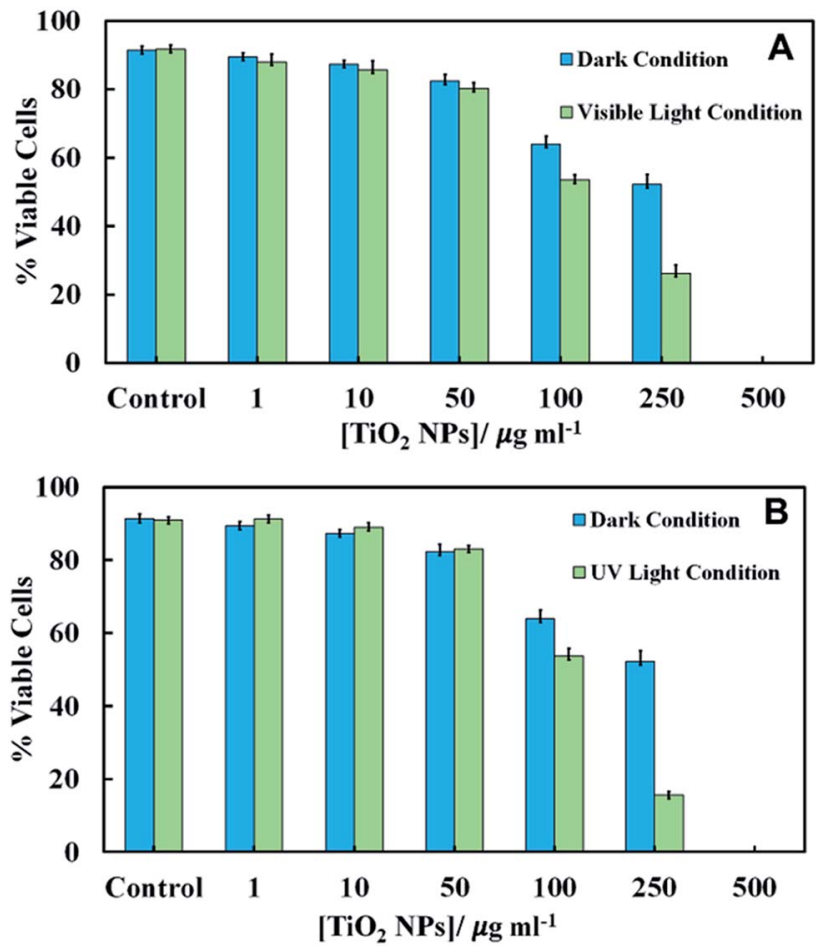

Fig. 4 (A) Comparison of the cell viability of $C$. reinhardtii as a function of the $\mathrm{TiO}_{2} \mathrm{NPs}$ concentration in dark conditions and in visible light after 6 hours of incubation. (B) Comparison of the $C$. reinhardtii cell viability as a function of the $\mathrm{TiO}_{2} \mathrm{NPs}$ concentrations in dark conditions and in UV light after 6 hours of incubation.

aqueous suspensions of the microalgae were incubated with aqueous suspensions of $\mathrm{TiO}_{2}$ NPs of various concentrations for several different periods of time. We examined the cell viability immediately after removing the excess of $\mathrm{TiO}_{2} \mathrm{NPs}$ from the cell suspension. The comparison of the cell viability of $C$. reinhardtii in dark and visible light conditions is presented in Fig. 4A for an exposure time of 6 hours. Note that immediately after incubation ( 0 hours), the viability of the microalgae gradually

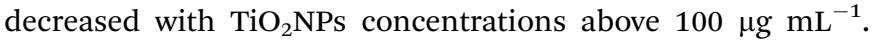
Fig. S7 (ESI†) shows similar results under visible light at various incubation times.

After 2-6 hours of incubation in visible light, the cell viability also decreased but at much lower $\mathrm{TiO}_{2}$ NPs concentrations, 10$250 \mu \mathrm{g} \mathrm{mL}^{-1}$ and above this limit, we found no viable cells in the samples. Fig. S8 (ESI $\dagger$ ) shows that at higher $\mathrm{TiO}_{2} \mathrm{NPs}$ concentrations $\left(>250 \mu \mathrm{g} \mathrm{mL} \mathrm{mL}^{-1}\right)$, the cells were highly aggregated possibly due to the cationic nature of the $\mathrm{TiO}_{2} \mathrm{NPs}$ surface in water, while at lower $\mathrm{TiO}_{2} \mathrm{NPs}$ concentrations $\left(50 \mu \mathrm{g} \mathrm{mL}^{-1}\right)$ they were fully dispersed. This can be explained by the fact that the positive surface charge of the $\mathrm{TiO}_{2} \mathrm{NPs}$ generally has a disruptive effect on the cell membranes.

One would expect that in the presence of UV light and oxygen, the reactive oxygen species produced from the $\mathrm{TiO}_{2} \mathrm{NPs}$ would not only oxidise the chlorophyll content in the microalgae, but could also exert oxidative stress to the cell nucleus, mitochondria and other organelles. Fig. S11 in ESI $\uparrow$ show that at low UV light exposure times there was pronounced toxic effect 
for $\mathrm{TiO}_{2} \mathrm{NPs}$ concentrations above $250 \mu \mathrm{g} \mathrm{mL}^{-1}$. At exposure times above 2 hours, a sharp decrease in the microalgae viability was observed for $\mathrm{TiO}_{2} \mathrm{NPs}$ concentrations from $50-250 \mu \mathrm{g} \mathrm{mL} \mathrm{mL}^{-1}$. However, at higher particle concentrations we cannot directly differentiate between these effects as all cells lost their viability. Fig. 4B shows that the toxicity effect of $\mathrm{TiO}_{2} \mathrm{NPs}$ on the microalgae irradiated with UV light for 6 hours is definitely higher than that with visible light at the same conditions (Fig. 4A). Fig. $4 \mathrm{~A}$ and $\mathrm{B}$ indicate that at low and moderate particle concentrations, the cationic nature of the $\mathrm{TiO}_{2} \mathrm{NPs}$ has much more disruptive effect on the cell viability (represented by the data in dark condition) than the additional effects of irradiation by visible and UV light.

\section{Chlorophyll content of $C$. reinhardtii after exposure to $\mathrm{TiO}_{2} \mathrm{NPs}$}

The effect of $\mathrm{TiO}_{2} \mathrm{NPs}$ on $C$. reinhardtii was also indirectly evaluated by determining the cells chlorophyll content as measure of their photosynthetic ability. Fig. 5 shows the total chlorophyll content (chlorophyll a and b) as a function of $\mathrm{TiO}_{2} \mathrm{NPs}$ concentration after 6 hours of exposure. Note that the cells apparently lose part of their chlorophyll content in the presence of $\mathrm{TiO}_{2} \mathrm{NPs}$ not only upon exposure to UV light, but also upon irradiation with visible light (Fig. 5A). Moderate loss of chlorophyll was found even in dark conditions.

However, we observed a sharp loss of the cells chlorophyll content upon irradiation with UV light (Fig. 5B) above particle concentration of $50 \mu \mathrm{g} \mathrm{mL} \mathrm{mL}^{-1}$ which is close to the threshold concentration where the cells start to lose their viability, as shown in Fig. 4. Note that with the UV light source (main peak at $365 \mathrm{~nm}$ ) used in our experiments, the microalgae cells alone did not lose their viability or discolour over the same period of time. Fig. S12 and S13 (ESI $\dagger$ ) present additional data about the cell chlorophyll content for different exposure times to $\mathrm{TiO}_{2} \mathrm{NPs}_{\text {in }}$ both visible and UV light, respectively. Fig. 5C shows the effect of $\mathrm{TiO}_{2} \mathrm{NPs}$ on the $C$. reinhardtii which clearly indicated that for the range of $50-500 \mu \mathrm{g} \mathrm{mL} \mathrm{m}^{-1}$ particle concentrations, a distinct discoloration of the cells chloroplasts was observed after 6 hours of exposure to UV light. The series of digital photographs presented in Fig. 5C show the discoloration of the microalgae suspension for different durations of exposure to $\mathrm{TiO}_{2}$ NPs. The decrease of cell chlorophyll content in dark conditions above $100 \mathrm{mg} \mathrm{mL}{ }^{-1} \mathrm{TiO}_{2} \mathrm{NPs}$ is surprising as they would not be expected to produce reactive oxygen species in the absence of UV/vis light. Note that the microalgae viability does not correlate $1: 1$ with their chlorophyll content. The dead cells can temporarily retain some residual amount of chlorophyll in their chloroplasts, although their cell membranes are compromised. This is clearly the case in Fig. 5 where a small amount of chlorophyll was extracted from the samples treated with $\mathrm{TiO}_{2}$ NPs at $500 \mu \mathrm{g} \mathrm{mL}{ }^{-1}$, which show $0 \%$ viability (Fig. 4A and B). The complete discolouration of the cells chlorophyll content requires higher $\mathrm{TiO}_{2} \mathrm{NPs}$ concentrations and/or longer exposure times to UV light and oxygen.

In order to examine the localisation of $\mathrm{TiO}_{2} \mathrm{NPs}$ around the cell membrane of $C$. reinhardtii we produced TEM images of the
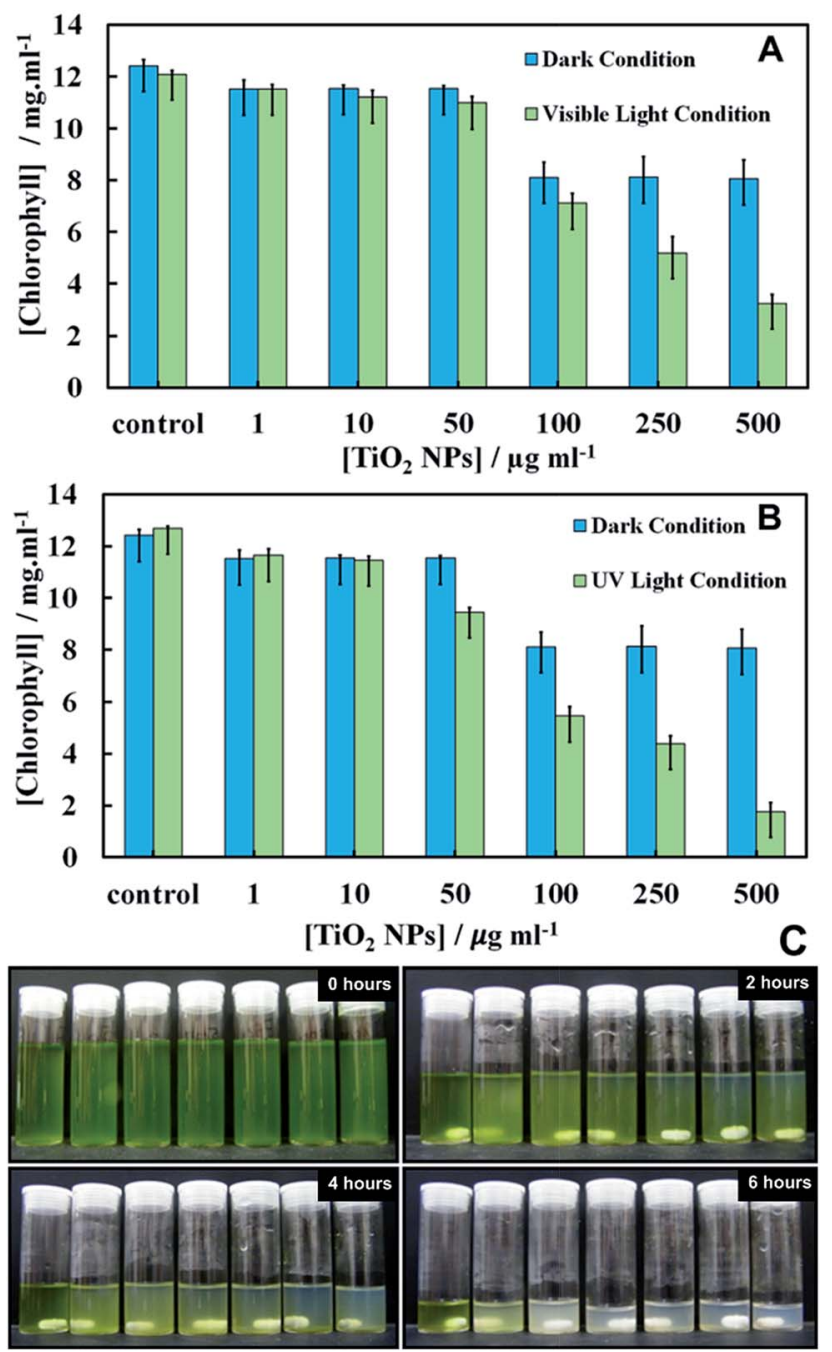

Fig. 5 (A) The effect of the $\mathrm{TiO}_{2} \mathrm{NPs}$ concentration on the chlorophyll content of green algae $C$. reinhardtii in dark conditions and under visible light after 6 hours exposure time. (B) The effect of the $\mathrm{TiO}_{2} \mathrm{NPs}$ concentration on the chlorophyll content of $C$. reinhardtii in dark conditions and upon illumination with UV light for 6 hours exposure time. The chlorophyll was extracted by using 80 vol\% aqueous acetone solution and analysed spectroscopically. (C) Optical images of $C$. reinhardtii samples after $0,2,4$ and 6 hours of illumination with UV light in the presence of $\mathrm{TiO}_{2} \mathrm{NPs}$ at the same concentration range $(0-$ $500 \mathrm{mg} \mathrm{L}^{-1}$ ) as in (A) and (B). The LHS test tubes on all four images in (C) represent the control sample of microalgae without $\mathrm{TiO}_{2} \mathrm{NPs}$.

microalgae cells after 6 hours of exposure to $\mathrm{TiO}_{2} \mathrm{NPs}$ in visible light. Fig. 6 shows TEM images of sections of microalgae cells incubated with $\mathrm{TiO}_{2} \mathrm{NPs}$ of different concentrations where it can be seen that the cell membranes have a dense coating of $\mathrm{TiO}_{2} \mathrm{NPs}$ and there is a limited penetration of nanoparticles inside the cells even at $100 \mu \mathrm{g} \mathrm{mL}^{-1}$. In addition, the cells organelles and the inner cell microstructure (Fig. 6B-D) look very different to the control sample untreated with $\mathrm{TiO}_{2} \mathrm{NPs}$ (Fig. 6A) which indicates that the $\mathrm{TiO}_{2} \mathrm{NPs}$ may interfere with the microalgae photosynthetic pathways even under irradiation with visible light.

We also checked for possible internalisation of the cationic $\mathrm{TiO}_{2}$ NPs in C. reinhardtii. ${ }^{26}$ Sectioned samples of the microalgae 

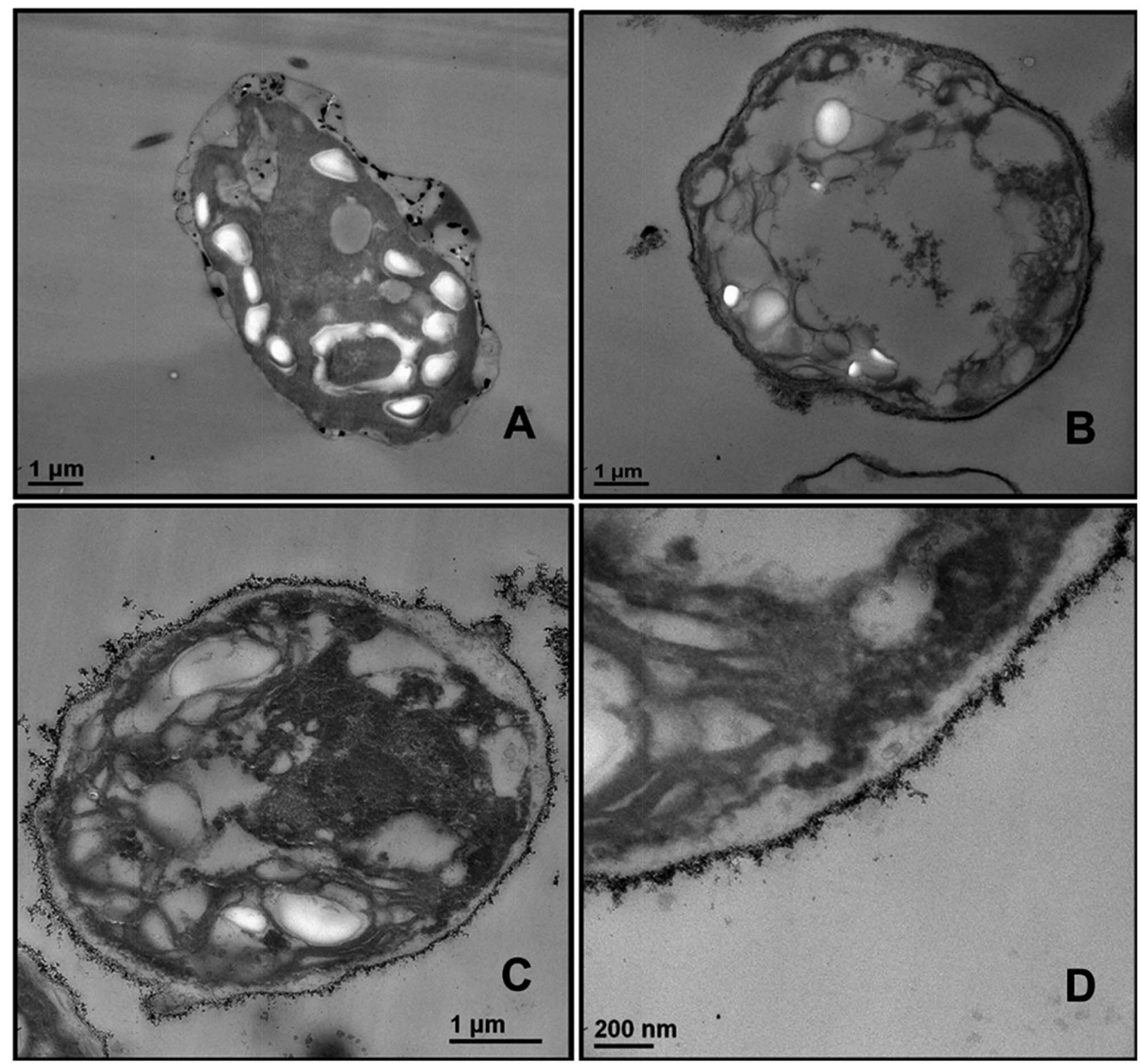

Fig. 6 TEM images of microtome-sectioned samples of $C$. reinhardtii cells after being incubated with 0,100 , and $500 \mu \mathrm{g} \mathrm{mL}-1$ TiO ${ }_{2} \mathrm{NPs}_{\mathrm{and}}$ irradiated for 6 hours with visible light. Image (A) represents the control sample of the cells without $\mathrm{TiO}_{2} \mathrm{NPs}$; image (B) corresponds to microalgae incubated with $100 \mu \mathrm{g} \mathrm{mL}^{-1} \mathrm{TiO}_{2} \mathrm{NPs}$; images (C) and (D) show the microstructure of a microalgae cell wall after incubation with $500 \mu \mathrm{g} \mathrm{mL}^{-1} \mathrm{TiO}_{2} \mathrm{NPs}$. We do not observe internalisation of $\mathrm{TiO}_{2} \mathrm{NPs}$ even at $500 \mu \mathrm{g} \mathrm{mL}^{-1}$ concentration. EDX results (Fig. S16, ESI $\dagger$ ) shows no titanium-content on the inside the sectioned microalgae.

exposed to $\mathrm{TiO}_{2} \mathrm{NPs}$ were analysed with EDX (Fig. S16, ESI $\dagger$ ) revealed that $\mathrm{TiO}_{2} \mathrm{NPs}$ accumulate only at the outer side of the cell membrane without evidence for further penetration in the cell interior. Reactive oxygen species produced by exposure to $\mathrm{TiO}_{2}$ NPs and oxygen in UV/visible light may also interfere with the cell chloroplasts and other vital organelles and disrupt the cell photosynthetic system which corresponds to higher toxicity. However, since we observed an adverse effect on the microalgae at high $\mathrm{TiO}_{2}$ NPs concentration in dark condition, this indicates that another possible mechanism of toxicity may also be in place in addition to the one discussed in the literature. ${ }^{26} \mathrm{We}$ envisage that most of the decrease of the percentage of viable microalgae cells in both visible light and dark conditions is probably due to the cell membrane disruption by the cationic nature of the $\mathrm{TiO}_{2} \mathrm{NPs}$ at this $\mathrm{pH}$.

\section{Nanotoxicity of $\mathrm{TiO}_{2} \mathrm{NPs}$ on yeast}

Recently, Kasemets et al. ${ }^{27}$ published a study on the effect of nano-grade $\mathrm{ZnO}, \mathrm{CuO}$, and $\mathrm{TiO}_{2}$ particles on the growth of yeast over 24 hours exposure time. They reported no effect on the growth of yeast from nano-sized and bulk $\mathrm{TiO}_{2}$ even at particle concentrations of $20000 \mu \mathrm{g} \mathrm{mL} \mathrm{m}^{-1}$. Other authors also indicated that the toxicity of metal oxide nanoparticles depends on the particle size and crystal structure. ${ }^{\mathbf{1 4}}$ These studies, however were 
conducted in the presence of growth media, some components of which (e.g. peptones) can also interact with the metal nanoparticles. In our experiments, we focussed on the effect of $\mathrm{TiO}_{2} \mathrm{NPs}$ on the yeast cell viability in the absence of growth media which enabled us to evaluate the interaction of between the cells and nanoparticles. We incubated samples of yeast cells with dispersed $\mathrm{TiO}_{2} \mathrm{NPs}$ at different particle concentrations for various periods of time for up to 24 hours in dark conditions and in UV light, respectively. Please note that the control sample of yeast survives without the media for this period of time, i.e. the effect is not due to the lack of nutrients. The yeast cell viability in each sample was determined as described in the previous section. We observed that the cells were highly aggregated after incubation with a high $\mathrm{TiO}_{2} \mathrm{NPs}$ concentrations, as shown in Fig. S14 (ESI $\dagger$ ). This result is similar to clustering of the $C$. reinhardtii cells in the presence of high concentrations of $\mathrm{TiO}_{2} \mathrm{NPs}$ which be explained with the positive surface charge of the nanoparticles which hetero-coagulate with the negatively charged cells.

Fig. 7 shows the cytotoxic effect on yeast at different concentrations of $\mathrm{TiO}_{2} \mathrm{NPs}$ (of hydrodynamic diameter $25 \mathrm{~nm}$ ) upon illumination with UV light for 24 hours. Our results indicate that the $\mathrm{TiO}_{2} \mathrm{NPs}$ have a weak effect on the yeast cells viability above $1000 \mathrm{mg} \mathrm{mL}^{-1}$ in dark conditions. The cytotoxic effect of the $\mathrm{TiO}_{2} \mathrm{NPs}$ on microalgae upon illumination with UV light is stronger and can be observed at much lower particle concentrations (above $100 \mathrm{mg} \mathrm{mL}^{-1}$ ). Fig. S15 (ESI $\dagger$ ) shows further data for the toxic effects of $\mathrm{TiO}_{2} \mathrm{NPs}$ on yeast at shorter exposure times in UV light and in dark conditions. For up to 6 hours of exposure, our data on cell viability agree with the findings of Kasemets $e t ~ a l .{ }^{27}$ who reported that yeast cells are insensitive even to extremely high $\mathrm{TiO}_{2} \mathrm{NPs}$ concentrations. However, our cell viability data are acquired in the absence of culture media whose components may also adsorb on the nanoparticles surface and change their interaction with the cells.

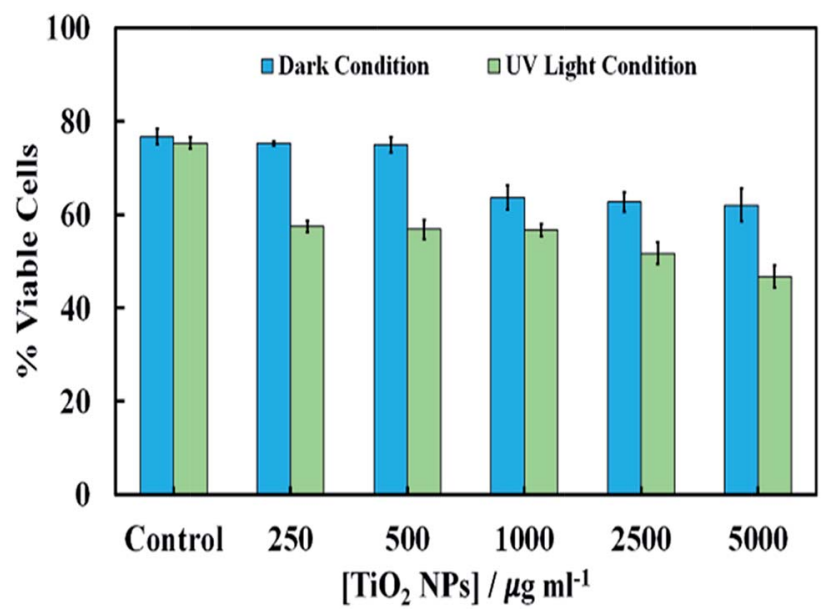

Fig. 7 The cell viability of S. cerevisiae after 24 hours of incubation at different concentrations of $\mathrm{TiO}_{2} \mathrm{NPS}$ in dark condition and in UV light compared with the control sample without $\mathrm{TiO}_{2} \mathrm{NPs}$.
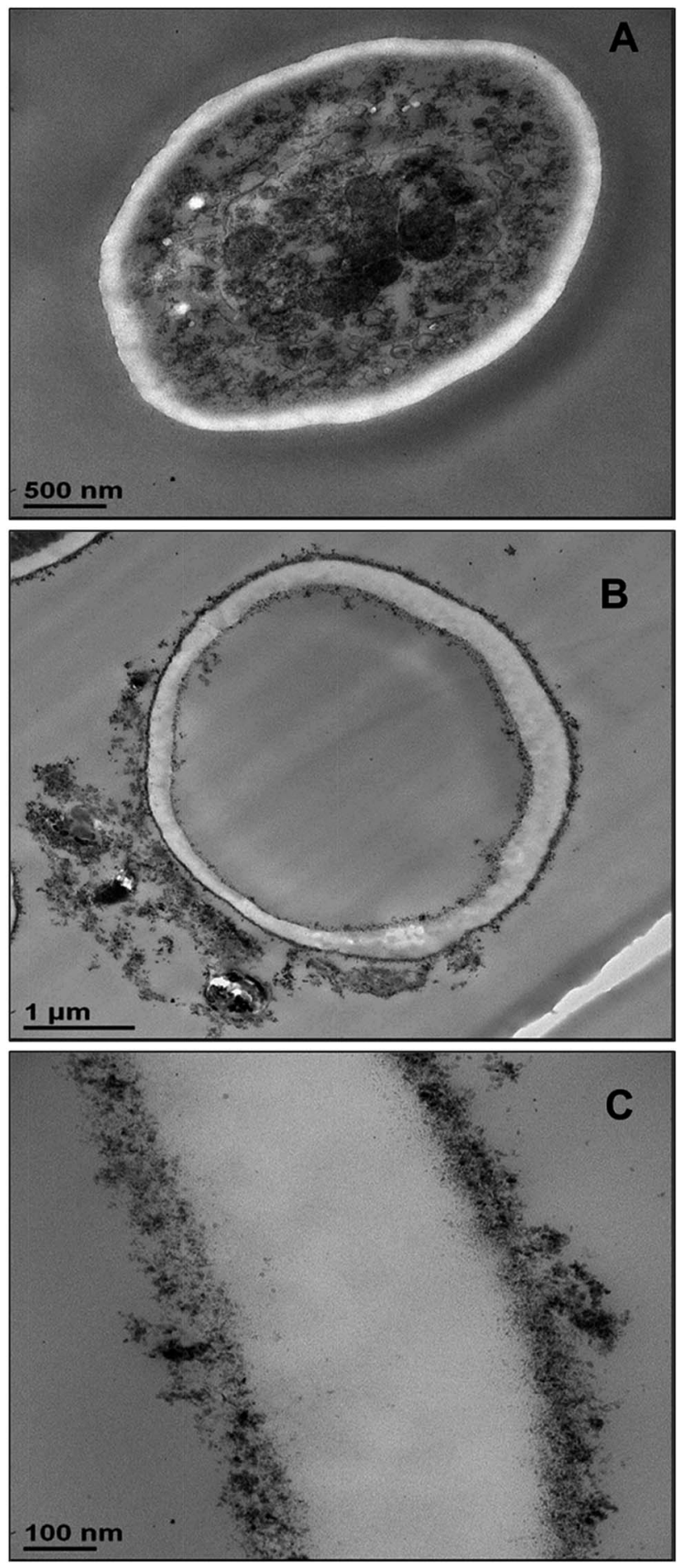

Fig. 8 TEM images of $S$. cerevisiae sectioned after 24 hours of irradiation with UV light and incubation in (A) Milli-Q water and (B) 5000 $\mu \mathrm{g} \mathrm{mL}{ }^{-1} \mathrm{TiO}_{2}$ NPs. (C) High resolution TEM image of the outer and inner cell wall of the yeast cell treated as in (B) which shows the attachment of $\mathrm{TiO}_{2} \mathrm{NPs}$ to the outer cell surface and indicates their internalisation inside the cell. Similar conclusion is obtained from EDX results (Fig. S17, ESI†).

In order to understand better the differences between the $\mathrm{TiO}_{2} \mathrm{NPs}$ effect on microalgae and yeast we used TEM to examine the yeast cells which were incubated with $\mathrm{TiO}_{2} \mathrm{NPs}$ for 
24 hours and treated similarly to the microalgae as shown in Fig. 6. Fig. 8B shows the TEM images of microtome-sectioned yeast cells after exposure to UV light and $5000 \mu \mathrm{g} \mathrm{mL}{ }^{-1} \mathrm{TiO}_{2}$ NPs for 24 hours compared with the control samples of yeast without exposure to $\mathrm{TiO}_{2} \mathrm{NPs}$ (Fig. 8A). One can see a build-up of $\mathrm{TiO}_{2}$ NPs both on the outer and the inner cell wall which indicates their penetration through the cell wall at high particle concentration. We confirmed this result by performing EDX on sectioned yeast which showed presence of Ti on both sides of the cell membrane (Fig. S17, ESI $\dagger$ ). However, the exposure of yeast to $\mathrm{TiO}_{2} \mathrm{NPs}$ in the same concentration range that cause cytotoxicity effect in C. reinhardtii (Fig. 6) did not lead to extensive particle internalisation and cell damage due to the much thicker cell wall of yeast $(\sim 200 \mathrm{~nm})$ compared to $C$. reinhardtii. The specific cytotoxicity of $\mathrm{TiO}_{2} \mathrm{NPs}$ in UV light occurs due to the generation of $\mathrm{OH}^{*}, \mathrm{O}_{2}{ }^{-}$, and $\mathrm{H}_{2} \mathrm{O}_{2}$ in their vicinity as they are deposited on the cell wall which leads to local oxidation of phospholipids from the cell membrane. In addition, the internalisation of $\mathrm{TiO}_{2} \mathrm{NPs}$ through the damaged cells walls subsequently may cause DNA damage, disruption of vital organelles and the electron transport chain, which leads to the cell death. The cells wall thickness determines the barrier for the $\mathrm{TiO}_{2} \mathrm{NPs}$ internalisation and their toxicity threshold.
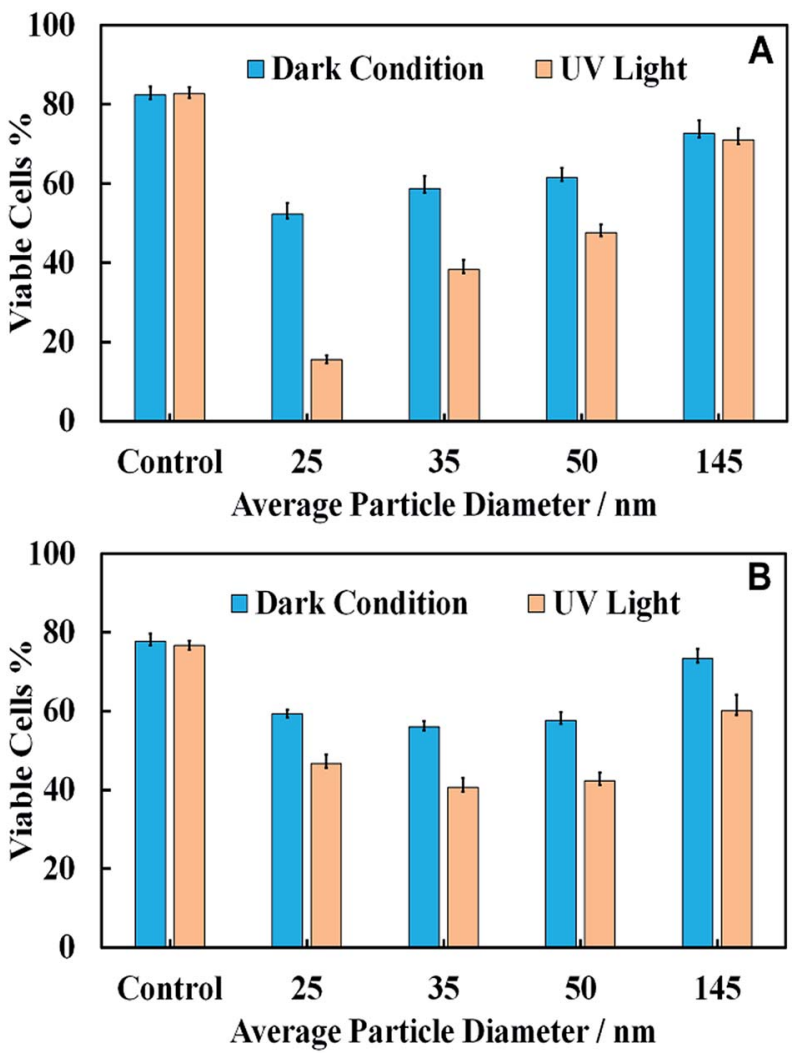

Fig. 9 (A) The cell viability of C. reinhardtii incubated with $\mathrm{TiO}_{2} \mathrm{NPs}$ of different average particle sizes ( $25 \mathrm{~nm}, 35 \mathrm{~nm}, 50 \mathrm{~nm}$ and $145 \mathrm{~nm}$ ) and total particle concentration of $250 \mu \mathrm{g} \mathrm{mL}^{-1}$ in dark conditions and in UV light for 6 hours. (B) The cell viability of S. cerevisiae incubated with $\mathrm{TiO}_{2} \mathrm{NPs}$ of different average particle sizes (the same as in (A)) but at total particle concentration of $2500 \mu \mathrm{g} \mathrm{mL}^{-1}$ in dark conditions and in UV light for 24 hours.

\section{Effect of the $\mathrm{TiO}_{2} \mathrm{NPs}$ size on microalgae and yeast cell} viability

We used a series of titania samples produced by thermal annealing at $400{ }^{\circ} \mathrm{C}, 600{ }^{\circ} \mathrm{C}$ and $800{ }^{\circ} \mathrm{C}$, followed by dispersing by sonication in aqueous solution to prepare samples of $\mathrm{TiO}_{2}$ NPs of particle diameters $25 \mathrm{~nm}, 35 \mathrm{~nm}, 50 \mathrm{~nm}$ and $145 \mathrm{~nm}$. A fixed amount of $\mathrm{TiO}_{2} \mathrm{NPs}$ of each sample was incubated with $C$.
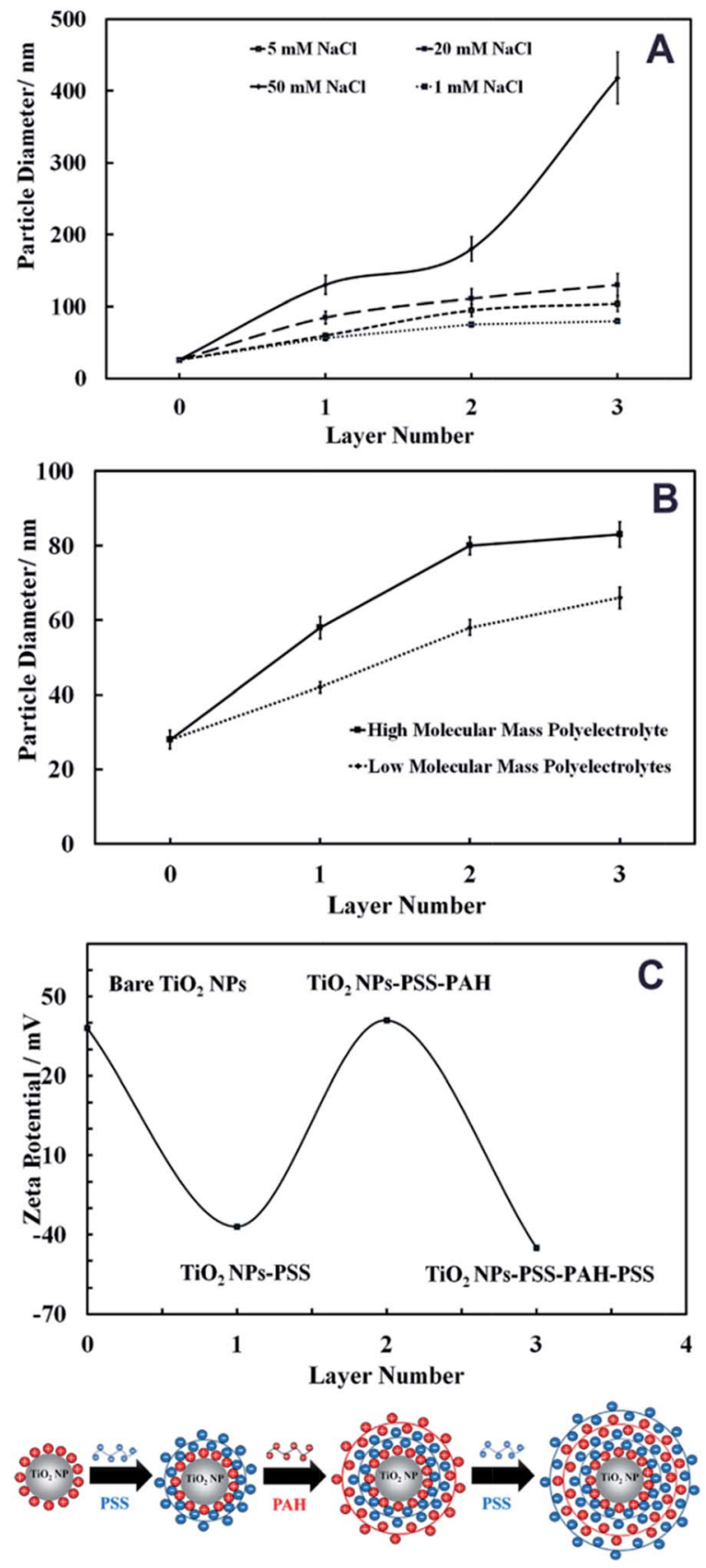

Fig. 10 (A) The effect of the solution ionic strength on the particle size distribution of $\mathrm{TiO}_{2} \mathrm{NPs}$ coated with anionic and cationic polyelectrolytes. (B) The particle diameter of the polyelectrolyte coated $\mathrm{TiO}_{2} \mathrm{NPs}$ as a function of number of deposited layers of polyelectrolytes with different molar mass. (C) The zeta potential of bare and multicoated $\mathrm{TiO}_{2} \mathrm{NPs}$ as a function of numbers of deposited layer of anionic and cationic polyelectrolytes (10 kDa PSS and $15 \mathrm{kDa} P A H)$ in $1 \mathrm{mM} \mathrm{NaCl}$. 
reinhardtii and $S$. cerevisiae and irradiated with UV light for $6 \mathrm{~h}$ and $24 \mathrm{~h}$, respectively. Control samples of the same compositions were kept in dark conditions for the same periods of time. Fig. 9 shows the effect of $\mathrm{TiO}_{2}$ NPs particle size on their toxicity for $C$. reinhardtii and $S$. cerevisiae. The data indicates that the smaller particle sizes had a higher toxic effect on both types of cells at the same particle concentration. The toxicity decreases with increasing particle size for both samples irradiated with UV light and those kept in dark conditions. This can be explained by the packing conditions of the $\mathrm{TiO}_{2} \mathrm{NPs}$ which allow more of the smaller nanoparticles to attach to the cell wall as compared to the case of larger nanoparticles. However, the effect is not so pronounced for $S$. cerevisiae.

Note that the toxic effect of the $145 \mathrm{~nm} \mathrm{TiO}_{2} \mathrm{NPs}$ is much lower than that of the smaller nanoparticles. This is apparently related to the fact that the $145 \mathrm{~nm}$ particles were obtained by dispersing titania annealed at $800{ }^{\circ} \mathrm{C}$ which corresponds to rutile, while the other three $\mathrm{TiO}_{2}$ NPs samples $(25 \mathrm{~nm}, 35 \mathrm{~nm}$ and $50 \mathrm{~nm}$ ) correspond to anatase form of titania. Since the former has a slightly negative zeta potential at $\mathrm{pH} 4$, this is likely to explain the reduced nanotoxicity of the rutile $\mathrm{TiO}_{2} \mathrm{NPs}$ with the lack of electrostatic adhesion with the cells.

Note that the $\mathrm{TiO}_{2}$ NPs samples used in Fig. 9 have not only different hydrodynamic diameters but also varying zeta potentials. The reason is that it is practically difficult to vary the particles size at fixed surface potentials as the smallest particle hydrodynamic diameter in solution is limited by the crystallite size of titania, which is controlled by the calcination temperature at the sample preparation stage. For unmodified $\mathrm{TiO}_{2}$ NPs the zeta potential depends on the size of the particle crystallites as well as the degree of aggregation. This is not unusual and is well documented with other materials. Table 1 clearly shows the link between the particle hydrodynamic diameter achieved by sonication in solution and the particle crystallite size. The negative zeta potential for $145 \mathrm{~nm} \mathrm{TiO}_{2} \mathrm{NPs}$ is because this is a rutile form of titania which has different isoelectric point (IEP) to anatase.

\section{Polyelectrolyte-functionalised $\mathrm{TiO}_{2} \mathrm{NPs}$}

We used the layer-by-layer assembly technique to coat $25 \mathrm{~nm}$ anatase $\mathrm{TiO}_{2}$ NPs with alternating layers of anionic (PSS) and cationic $(\mathrm{PAH})$ polyelectrolytes using the protocols described in the previous section. Since the anatase $\mathrm{TiO}_{2} \mathrm{NPs}$ are cationic below pH 6.5 the first layer was PSS, an anionic polyelectrolyte that formed negatively charged $\mathrm{TiO}_{2} \mathrm{NPs} / \mathrm{PSS}$. Further coating with $\mathrm{PAH}$ gave positively charged $\mathrm{TiO}_{2} \mathrm{NPs} / \mathrm{PSS} / \mathrm{PAH}$. Finally, by using an extra coating of PSS, we obtained anionic $\mathrm{TiO}_{2} \mathrm{NPs} / \mathrm{PSS} /$ PAH/PSS particles. Since the coating was affected by many parameters such as the ionic strength and the molar mass of the polyelectrolyte (which can cause partial aggregation), we examined the average particle size after each polyelectrolyte coating at several different ionic strengths. Fig. 10A shows the effect of the ionic strength on the size of the $\mathrm{TiO}_{2} \mathrm{NPs}$ coated with anionic and cationic polyelectrolytes. Note that the particle hydrodynamic diameter increases with an increase in $\mathrm{NaCl}$ concentration, largely due to the partial coagulation of the
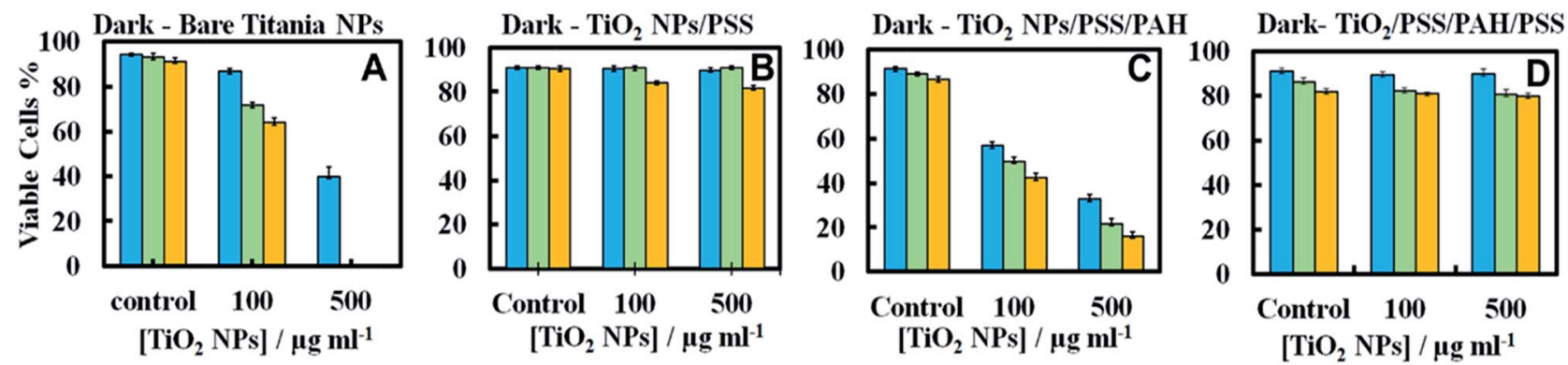

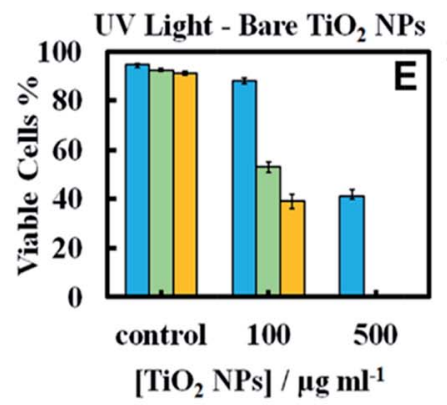

$\square$ 0 hours

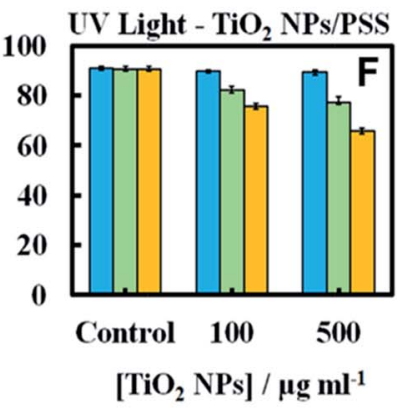

$\square 3$ hours

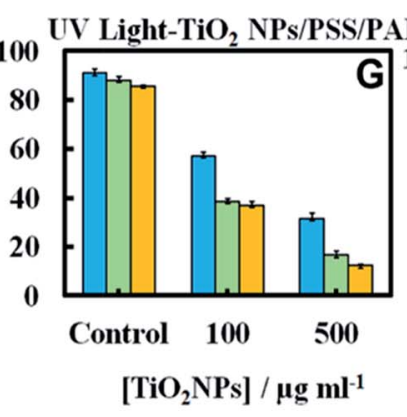

$\square 6$ hours

Fig. 11 The effect of anatase $\mathrm{TiO}_{2} \mathrm{NPs}$ coated with different number of layers of anionic (PSS) and cationic (PAH) polyelectrolytes on the viability of $C$. reinhardtii microalgae at different particle concentrations $\left(0,100\right.$ and $\left.500 \mu \mathrm{gL}^{-1}\right)$. The cells were incubated with the TiO $\mathrm{NPs}_{\mathrm{s}}$ for at $0 \mathrm{~h}$, $3 \mathrm{~h}$ and $6 \mathrm{~h}$ exposure times in dark conditions (A-D) and in UV light $(\mathrm{E}-\mathrm{H})$, respectively. The cytotoxic effect on the microalgae cells was assessed for: (A and E) bare $\mathrm{TiO}_{2} \mathrm{NPs}$; ( $\mathrm{B}$ and F) $\mathrm{TiO}_{2} \mathrm{NPs} / \mathrm{PSS}$; ( $\mathrm{C}$ and $\mathrm{G}$ ) $\mathrm{TiO}_{2} \mathrm{NPs} / \mathrm{PSS} / \mathrm{PAH}$ and $\left(\mathrm{D}\right.$ and $\mathrm{H}$ ) $\mathrm{TiO}_{2} \mathrm{NPs} / \mathrm{PSS} / \mathrm{PAH} / \mathrm{PSS}$ at different nanoparticle concentrations and exposure times. 
polyelectrolyte-coated $\mathrm{TiO}_{2} \mathrm{NPs}$. This occurs during the coating stages due to the diminished electrostatic repulsion at higher salt concentrations. The optimal concentration of $\mathrm{NaCl}$ solution, where the coated $\mathrm{TiO}_{2} \mathrm{NPs}$ are still nano-sized, was found to be $1 \mathrm{mM}$. We also carried out the layer-by-layer coating using two batches of PSS and PAH with different molar masses and examined the corresponding diameter of the coated $\mathrm{TiO}_{2} \mathrm{NPs}$. As Fig. 10B shows, it was found that the lower the molar mass of the polyelectrolyte, the smaller the hydrodynamic diameter of the polyelectrolyte coated $\mathrm{TiO}_{2} \mathrm{NPs}$; therefore, $10 \mathrm{kDa}$ PSS and $15 \mathrm{kDa}$ PAH were chosen for coating titania NPs. We also measured the zeta potential of the $\mathrm{TiO}_{2} \mathrm{NPs}$ after each coat with anionic or cationic polyelectrolytes which is presented in
Fig. 10C as a function of the number of polyelectrolyte layer. It can be seen that the zeta potential of the polyelectrolyte coated $\mathrm{TiO}_{2}$ NPs alternates with the coating with oppositely charged polyelectrolytes similarly to other studies reported in the literature..$^{28-30}$

\section{Nanotoxicity of polyelectrolyte-coated $\mathrm{TiO}_{2} \mathrm{NPs}$ on $C$. reinhardtii}

Since the adhesion of the $\mathrm{TiO}_{2} \mathrm{NPs}$ to the cell membrane is largely driven by electrostatic interactions, we examined the cytotoxicity of $\mathrm{TiO}_{2} \mathrm{NPs}$ coated with varying number of polyelectrolyte layers and compared them with the bare $\mathrm{TiO}_{2} \mathrm{NPs}$. Fig. $11 \mathrm{~A}$ and $\mathrm{E}$ represent the cytotoxic effect of bare $\mathrm{TiO}_{2} \mathrm{NPs}_{\mathrm{in}}$
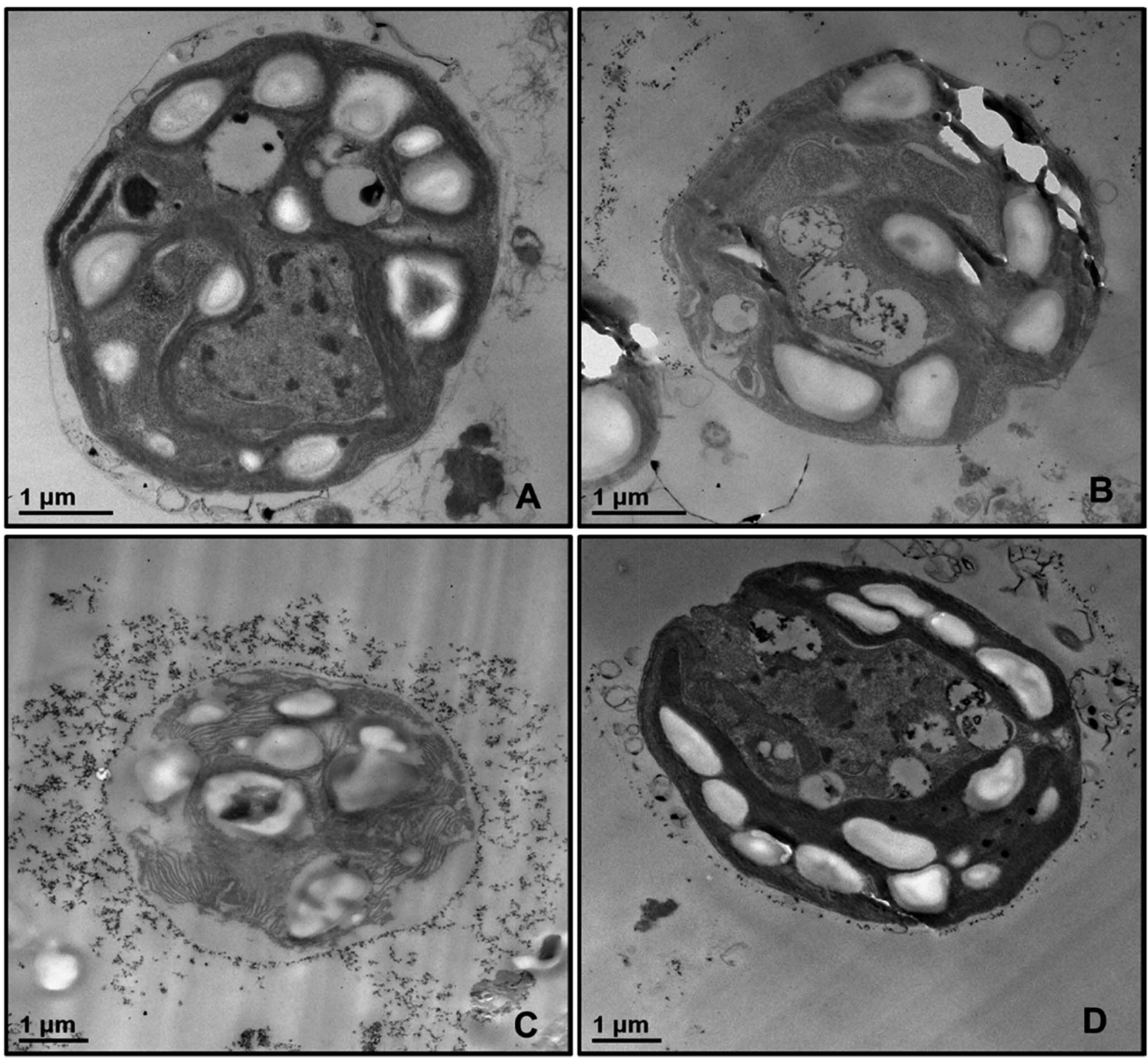

Fig. 12 TEM images of microtome-sectioned C. reinhardtii microalgae cells after being incubated for 6 hours with polyelectrolyte-coated $\mathrm{TiO}_{2} \mathrm{NPS}$ while illuminated with UV light. The $\mathrm{TiO}_{2} \mathrm{NPs}$ have been modified by deposition of different number layers of anionic (PSS) and cationic (PAH) polyelectrolytes. (A) The control sample of the microalgae without $\mathrm{TiO}_{2} \mathrm{NPs}$. The microalgae after being incubated with (B) $\mathrm{TiO}_{2} \mathrm{NPs} / \mathrm{PSS}$; (C) $\mathrm{TiO}_{2} \mathrm{NPs} / \mathrm{PSS} / \mathrm{PAH}$ and (D) $\mathrm{TiO}_{2} \mathrm{NPs} / \mathrm{PSS} / \mathrm{PAH} / \mathrm{PSS}$. 
dark conditions and in UV light while Fig. 11B and $\mathrm{F}$ give the same effect of $\mathrm{TiO}_{2} \mathrm{NPs}$ coated with a single layer of PSS. We found no pronounced toxicity of $\mathrm{TiO}_{2} \mathrm{NPs} / \mathrm{PSS}$ on the microalgae in dark conditions at this range of particle concentrations irrespectively of the time of exposure. The toxic effect of $\mathrm{TiO}_{2}$ NPs/PSS under UV light is also much lower than the one of the bare $\mathrm{TiO}_{2} \mathrm{NPs}$. The difference between the cell viability in Fig. $11 \mathrm{~B}$ and $\mathrm{F}$ is solely due to the photo activity of the titania nanoparticles. One may conclude that the functionalization of the $\mathrm{TiO}_{2} \mathrm{NPs}$ with anionic polyelectrolyte reduced its nanotoxicity probably because of the electrostatic repulsion of the coated nanoparticles from the cell surface as both of them have a negative surface charge (see also Fig. 10C). We observed a very similar effect for $\mathrm{TiO}_{2} \mathrm{NPs} / \mathrm{PSS} / \mathrm{PAH} / \mathrm{PSS}$ which is shown in Fig. 11D and $\mathrm{H}$ for these anionic nanoparticles. However, the introduction of a second coating of the cationic polyelectrolyte PAH turns the $\mathrm{TiO}_{2} \mathrm{NPs} / \mathrm{PSS} / \mathrm{PAH}$ nearly as toxic to the microalgae as the bare $\mathrm{TiO}_{2}$ NPs. The later effect can be seen in both Fig. $11 \mathrm{C}$ and G. It is interesting that at lower $\mathrm{TiO}_{2} \mathrm{NPs} / \mathrm{PSS} / \mathrm{PAH}$ concentrations $\left(100 \mathrm{mg} \mathrm{mL}^{-1}\right)$ these cationic coated particles are even more toxic than the bare $\mathrm{TiO}_{2} \mathrm{NPs}$ irrespectively of the time of exposure in both dark and UV light conditions. However, at higher concentrations, the bare $\mathrm{TiO}_{2} \mathrm{NPs}$ exhibit higher toxicity to microalgae than coated $\mathrm{TiO}_{2} \mathrm{NPs} / \mathrm{PSS} / \mathrm{PAH}$. This pattern of alternating toxicity of the polyelectrolyte coated $\mathrm{TiO}_{2}$ NPs seems to be consistent with their surface charge and the resulting electrostatically driven adhesion to the negatively charged cell wall surface. The cationic nanoparticles (the bare $\mathrm{TiO}_{2} \mathrm{NPs}$ and $\mathrm{TiO}_{2} \mathrm{NPs} / \mathrm{PSS} / \mathrm{PAH}$ ) have higher nanotoxicitiy than their anionic versions, $\mathrm{TiO}_{2} \mathrm{NPs} / \mathrm{PSS}$ and $\mathrm{TiO}_{2} \mathrm{NPs} / \mathrm{PSS} / \mathrm{PAH} / \mathrm{PSS}$.

In order to examine the build-up of $\mathrm{TiO}_{2} \mathrm{NPs}$ on the microalgae cell surface we incubated them with the same range of polyelectrolyte-coated $\mathrm{TiO}_{2} \mathrm{NPs}$ followed by their removal from the nanoparticle suspension after fixed time of exposure to UV light. The cell samples were sectioned and imaged with TEM as described in the previous section. Fig. 12 displays TEM images of $C$. reinhardtii for $\mathrm{TiO}_{2} \mathrm{NPs}$ coated with different number of anionic (PSS) and cationic (PAH) polyelectrolytes layers after incubation for up to 6 hours in dark conditions and in UV light. Note that there are very few $\mathrm{TiO}_{2} \mathrm{NPs} / \mathrm{PSS}$ and $\mathrm{TiO}_{2} \mathrm{NPs} / \mathrm{PSS} / \mathrm{PAH} /$ PSS attached to the cells (Fig. 12B and D) while we observe a significant build-up of $\mathrm{TiO}_{2} \mathrm{NPs} / \mathrm{PSS} / \mathrm{PAH}$ on the cell wall (Fig. 12C). These results are consistent with the nanotoxicity pattern of the polyelectrolyte-coated $\mathrm{TiO}_{2} \mathrm{NPs}$ on $C$. reinhardtii displayed in Fig. 11. One may speculate that the poor attachment of the anionic particles $\mathrm{TiO}_{2} \mathrm{NPs} / \mathrm{PSS}$ and $\mathrm{TiO}_{2} \mathrm{NPs} / \mathrm{PSS} /$ $\mathrm{PAH} / \mathrm{PSS}$ to the cells as confirmed by the TEM images corresponds to less disruption of the cell membranes and to lower oxidative stress in UV light as the ROS are produced around nanoparticles the are in the bulk of the suspension rather than on the cell walls. However, as can be seen in Fig. 6C and D for the bare $\mathrm{TiO}_{2} \mathrm{NPs}$ and Fig. $12 \mathrm{C}$ for the $\mathrm{TiO}_{2} \mathrm{NPs} / \mathrm{PSS} / \mathrm{PAH}$, there is an effective hetero-coagulation of the cationic $\mathrm{TiO}_{2} \mathrm{NPs}$ on the anionic cell walls which corresponds to much higher local particle concentration that subsequently has a highly disruptive effect on the cell viability ( $c f$. Fig. 11A, C, E and G).

\section{Nanotoxicity of polyelectrolyte-coated $\mathrm{TiO}_{2} \mathrm{NPs}$ on yeast}

We conducted similar tests with yeast cells and polyelectrolytecoated $\mathrm{TiO}_{2} \mathrm{NPs}$ where the cells were removed from their culture media. Fig. 13 compares the impact of bare and multilayercoated $\mathrm{TiO}_{2} \mathrm{NPs}$ with PSS and $\mathrm{PAH}$ polyelectrolytes at different particle concentrations on the yeast cell viability. Note that for
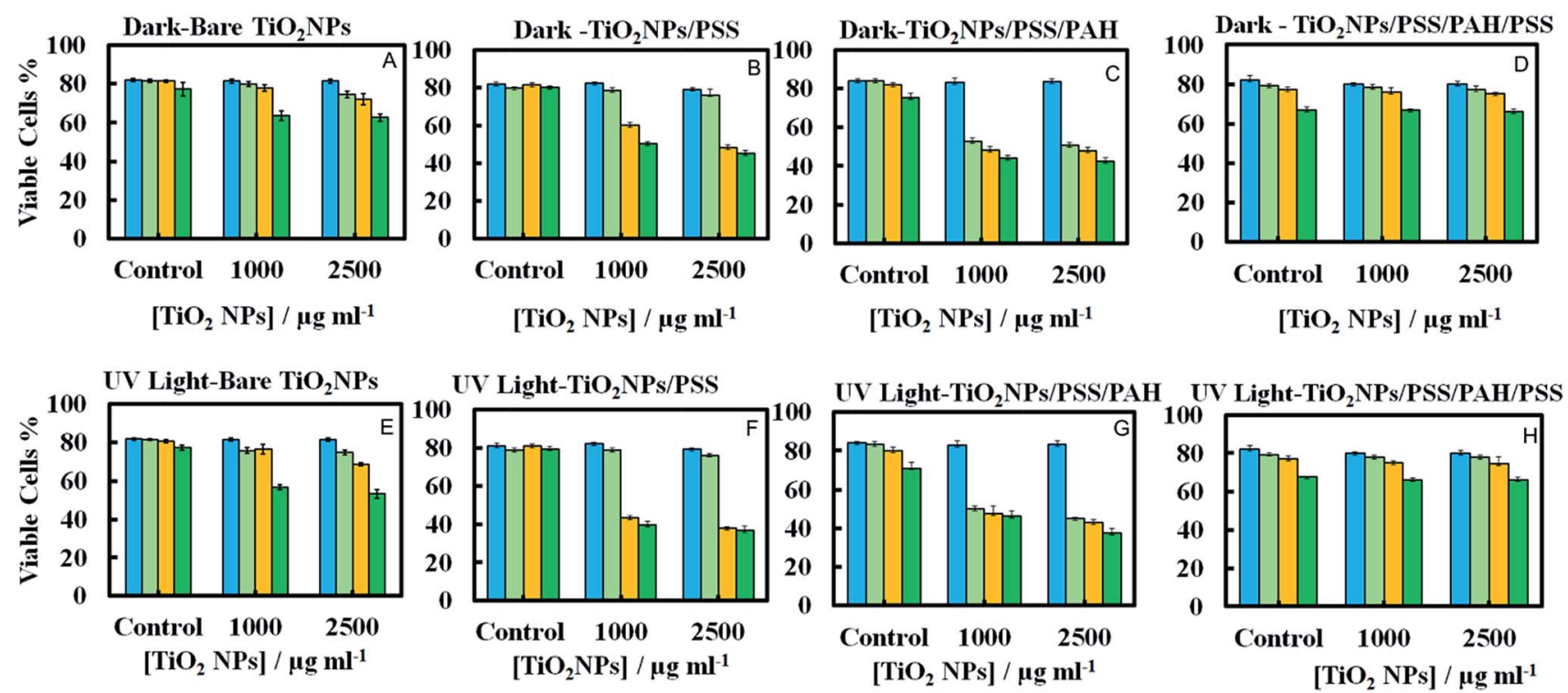

$\square 0$ hours $\square 6$ hours $\square 12$ hours $\square 24$ hours

Fig. 13 The cell viability of yeast upon incubation of bare and polyelectrolyte-coated anatase $\mathrm{TiO}_{2} \mathrm{NPs}$ of different particle concentrations $(0$, 1000, and $2500 \mu \mathrm{g} \mathrm{mL}^{-1}$ ) in dark conditions (A-D) and in UV light (E-H) at $0 \mathrm{~h}, 6 \mathrm{~h}, 12 \mathrm{~h}$ and $24 \mathrm{~h}$ exposure times. The yeast cells were incubated with: (A and E) bare $\mathrm{TiO}_{2} \mathrm{NPs}$; ( $\mathrm{B}$ and F) $\mathrm{TiO}_{2} \mathrm{NPs} / \mathrm{PSS}$; (C and G) $\mathrm{TiO}_{2} \mathrm{NPs} / \mathrm{PSS} / \mathrm{PAH}$ and $\left(\mathrm{D}\right.$ and $\mathrm{H}$ ) $\mathrm{TiO}_{2} \mathrm{NPs} / \mathrm{PSS} / \mathrm{PAH} / \mathrm{PSS}$. 
exposure times up to 6 hours, no measurable change in the yeast cell viability was observed for $\mathrm{TiO}_{2} \mathrm{NPs} / \mathrm{PSS}$ and $\mathrm{TiO}_{2} \mathrm{NPs} /$ $\mathrm{PSS} / \mathrm{PAH} / \mathrm{PSS}$ even at high particle concentrations. We also did not see significant difference between the samples kept in dark conditions or in UV light at the same particle concentration. However, for longer incubations times, the cationic nanoparticles $\mathrm{TiO}_{2} \mathrm{NPs} / \mathrm{PSS} / \mathrm{PAH}$ are showing a significant toxic effect on yeast even at moderate particle concentrations. A strong effect of the bare $\mathrm{TiO}_{2} \mathrm{NPs}$ on yeast cells viability was observed upon illumination with UV light at high particle concentrations. It is worth mentioning that no significant toxic effect was detected for bare $\mathrm{TiO}_{2}$ NPs in dark conditions at the same particle concentration range. These results call for some discussion with regard to the possible factors that may contribute to the nanotoxicity of the coated $\mathrm{TiO}_{2} \mathrm{NPs}$ on yeast, which differ from their effect on the microalgae cells. Since yeast cells have much thicker cell walls $(\sim 200 \mathrm{~nm})$ than microalgae, the data suggest that it takes a much higher nanoparticle concentration to impact the yeast cells viability (see also Fig. 7). However, upon illumination with UV light, the cell walls are likely to sustain greater damage from the ROS generated in their vicinity which may facilitate further $\mathrm{TiO}_{2} \mathrm{NPs}$ internalisation at higher concentrations and exposure times. Upon incubation with the anionic particles, $\mathrm{TiO}_{2} \mathrm{NPs} / \mathrm{PSS} / \mathrm{PAH} /$ PSS, however, we did not observe significant difference between the yeast cells viability both in dark conditions and in UV light for up to 24 hours of exposure except at very high particle concentrations.

The increased toxicity of the $\mathrm{TiO}_{2} \mathrm{NPs} / \mathrm{PSS}$ (Fig. 13B) compared to $\mathrm{TiO}_{2} \mathrm{NPs} / \mathrm{PSS} / \mathrm{PAH} / \mathrm{PSS}$ (Fig. 13D) is likely due to

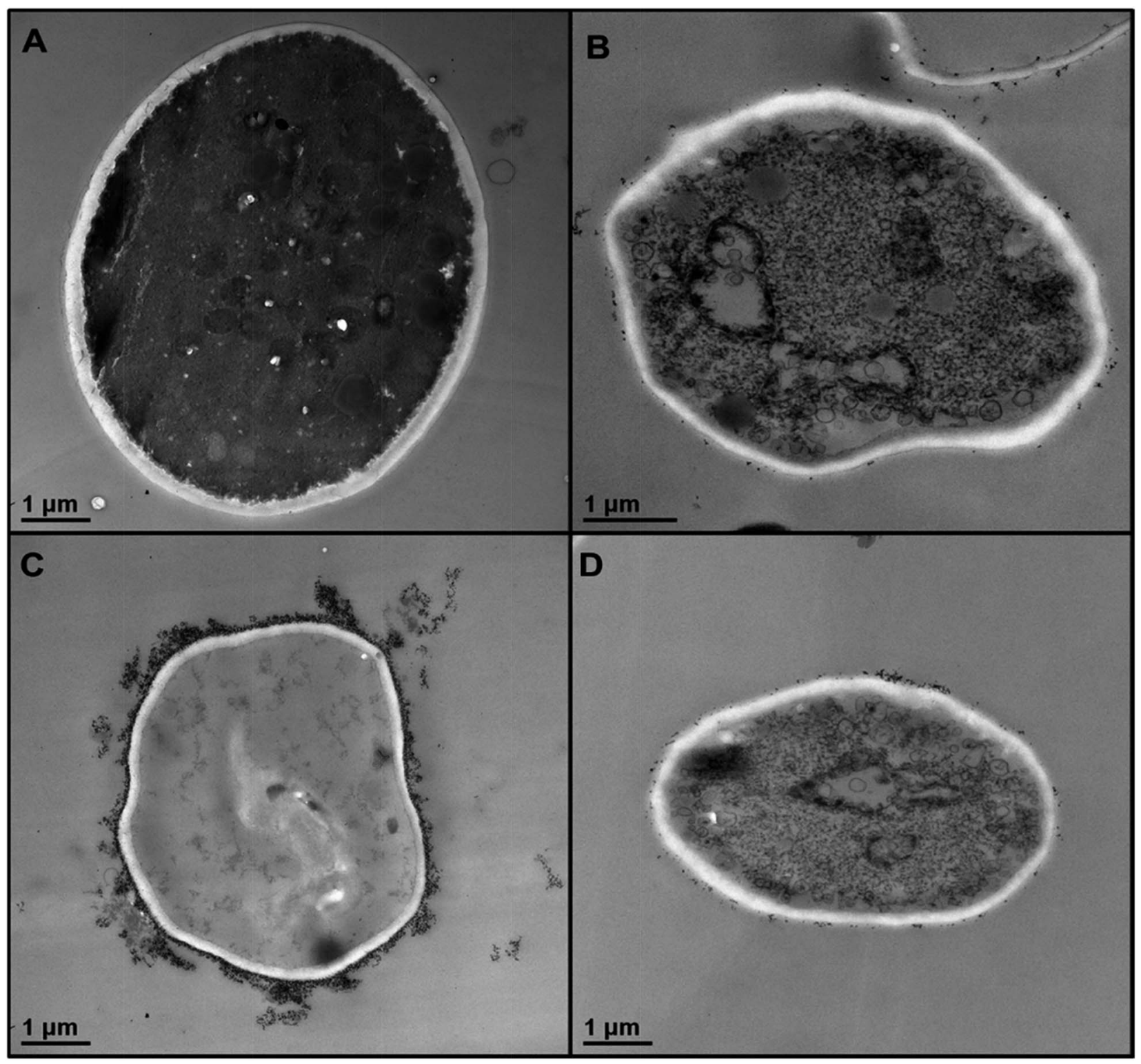

Fig. 14 TEM images of microtome sectioned yeast cells after being incubated for 24 hours under UV light with $\mathrm{TiO}_{2} \mathrm{NPS}_{\mathrm{S}} \mathrm{coated}$ with different number of polyelectrolyte layers: (A) control sample without $\mathrm{TiO}_{2} \mathrm{NPs}$. (B) Yeast cell incubated with $\mathrm{TiO}_{2} \mathrm{NPs} / \mathrm{PSS}$. (C) Yeast cells incubated with $\mathrm{TiO}_{2} \mathrm{NPs} / \mathrm{PSS} / \mathrm{PAH}$. (D) Yeast cells incubated with $\mathrm{TiO}_{2} \mathrm{NPs} / \mathrm{PSS} / \mathrm{PAH} / \mathrm{PSS}$. 
the thicker polyelectrolyte shell of the $\mathrm{TiO}_{2} \mathrm{NPs} / \mathrm{PSS} / \mathrm{PAH} / \mathrm{PSS}$. The ROS generating $\mathrm{TiO}_{2} \mathrm{NPs}$ cores are closer to the cell membranes for $\mathrm{TiO}_{2} \mathrm{NPs} / \mathrm{PSS}$ than for $\mathrm{TiO}_{2} \mathrm{NPs} / \mathrm{PSS} / \mathrm{PAH} / \mathrm{PSS}$. One may conclude that by coating the $\mathrm{TiO}_{2} \mathrm{NPs}$ with an outer anionic polyelectrolyte layer their cytotoxicity is greatly reduced for both yeast and microalgae due to the electrostatic repulsion between the cells surface and the nanoparticles. Fig. 14 shows TEM images of yeast cells incubated with $\mathrm{TiO}_{2} \mathrm{NPs}$ coated with polyelectrolyte layer of different surface charge. The TEM images in Fig. 14B and D support our hypothesis that the electrostatic repulsion between the negatively charged cell walls and the anionic nanoparticles, $\mathrm{TiO}_{2} \mathrm{NPs} / \mathrm{PSS}$ and $\mathrm{TiO}_{2} \mathrm{NPs} / \mathrm{PSS} /$ $\mathrm{PAH} / \mathrm{PSS}$, leads to reduced adhesion onto the cell surface. Fig. 14C however, shows a much larger build-up of cationic nanoparticles $\mathrm{TiO}_{2} \mathrm{NPs} / \mathrm{PSS} / \mathrm{PAH}$ which leads to the higher nanotoxicity for yeast both in dark conditions and in UV light. Nano-sized titania can be harmful to the environment as it is a powerful cell membrane disruptor due to its cationic nature and photo-activity which can make an adverse impact on aquatic organisms especially the ones in the root of the food chain. Our study shows for the first time that coating $\mathrm{TiO}_{2} \mathrm{NPs}$ with anionic polyelectrolytes as terminal layer greatly reduces their toxicity on algae and yeast as well as the toxicity threshold concentrations. Our study, as outlined above indicates a way of reducing toxicity of $\mathrm{TiO}_{2} \mathrm{NPs}$ by pre-coating them with anionic polymers. An additional improvement, which will be addressed in a follow up publication, would be to use layers of biocompatible anionic polymers to reduce the ecological footprint of such nanomaterials upon their post use release into the environment. It is also worth exploring the possible degradation of the polyelectrolyte coating on the $\mathrm{TiO}_{2} \mathrm{NPs}$ upon long-term exposure to UV light and oxygen.

\section{Conclusions}

We synthesised a range of titania nanoparticles of different crystallite size and characterised their surface charge and average hydrodynamic diameter in aqueous solutions. We studied the effect of the $\mathrm{TiO}_{2} \mathrm{NPs}$ hydrodynamic diameter on their toxicity for $C$. reinhardtii microalgae and yeast. In our nanotoxicity studies we separated the cells from their growth media to avoid any interferences with the $\mathrm{TiO}_{2} \mathrm{NPs}$. Our results indicate that smaller $\mathrm{TiO}_{2} \mathrm{NPs}$ have higher toxicity than larger ones, with the anatase form of the $\mathrm{TiO}_{2} \mathrm{NPs}$ having higher impact on the cell viability than the rutile form. We found that the bare anatase $\mathrm{TiO}_{2} \mathrm{NPs}$ are cationic below pH 6.5 which explains their adhesion to the cell walls of both microalgae and yeast.

Irradiation of the microalgae cells with UV light (peak at $365 \mathrm{~nm}$ ) had bigger impact on their viability in the presence of $\mathrm{TiO}_{2} \mathrm{NPs}$ compared with the same experiments conducted in dark conditions. Surprisingly, illumination with visible light also made the $\mathrm{TiO}_{2} \mathrm{NPs}$ more toxic to the microalgae compared to the ones in dark conditions. The experiment showed that $\mathrm{TiO}_{2} \mathrm{NPs}$ at concentrations above $50 \mu \mathrm{g} \mathrm{mL} \mathrm{m}^{-1}$ noticeably affect the microalgae viability while particle concentrations higher than $250 \mu \mathrm{g} \mathrm{mL} \mathrm{m}^{-1}$ led to complete loss of viability. Our tests also showed a decrease in the chlorophyll content after prolonged exposure to $\mathrm{TiO}_{2} \mathrm{NPs}$ in $\mathrm{UV}$ and visible light. This indicated that $\mathrm{TiO}_{2} \mathrm{NPs}$ can not only disrupt the cell membranes but also can interfere with the cell chloroplasts. The results with yeast cells showed similar trends but the nanotoxicity concentration threshold $\mathrm{TiO}_{2} \mathrm{NPs}$ was about one order of magnitude higher due to the much thicker yeast cells walls.

We also produced polyelectrolyte-coated $\mathrm{TiO}_{2} \mathrm{NPs}$ with up to 4 layers of polyelectrolytes of alternating charge (PSS and PAH) using the layer-by-layer technique. Cell viability tests showed that their nanotoxicity alternates with the particles surface charge and depends on the last coat of polyelectrolytes. Anionic nanoparticles as $\mathrm{TiO}_{2} \mathrm{NPs} / \mathrm{PSS}$ and $\mathrm{TiO}_{2} \mathrm{NPs} / \mathrm{PSS} / \mathrm{PAH} / \mathrm{PSS}$ showed much lower nanotoxicity than the cationic ones, $\mathrm{TiO}_{2}{ }^{-}$ $\mathrm{NPs} / \mathrm{PSS} / \mathrm{PAH}$ and bare $\mathrm{TiO}_{2} \mathrm{NPs}$, respectively. This is explained by the poor adhesion of the anionic particles to the cell walls due to their electrostatic repulsion and the amplification of the particle-cell adhesion in the case of cationic $\mathrm{TiO}_{2} \mathrm{NPs}$. These results were backed by TEM images of sectioned microalgae and yeast cells. The results of this study can benefit the understanding the interaction mechanisms of surface modified $\mathrm{TiO}_{2} \mathrm{NPs} / \mathrm{PSS}$ with living cells and determine the factors which control their nanotoxicity.

\section{Acknowledgements}

M.A. thanks the Iraqi Government, the Higher Committee for Education Development of Iraq and the Green University of Qasim, Babylon, Iraq for the financial support for his PhD study during the work on this project.

\section{Notes and references}

1 P. G. Barlow, K. Donaldson, J. MacCallum, A. Clouter and V. Stone, Toxicol. Lett., 2005, 155, 397-401.

2 C. Medina, M. Santos-Martinez, A. Radomski, O. Corrigan and M. Radomski, Br. J. Pharmacol., 2007, 150, 552-558.

3 N. Künzli, M. Jerrett, W. J. Mack, B. Beckerman, L. Labree, F. Gillil, D. Thomas, J. Peters and H. N. Hodis, Environ. Health Perspect., 2005, 113, 201-206.

4 C. Pelucchi, E. Pira, G. Piolatto, M. Coggiola, P. Carta and C. La Vecchia, Ann. Oncol., 2006, 17, 1039-1050.

5 S. Singh, T. Shi, R. Duffin, C. Albrecht, D. van Berlo, D. Höhr, B. Fubini, G. Martra, I. Fenoglio and P. J. Borm, Toxicol. Appl. Pharmacol., 2007, 222, 141-151.

6 J. Ai, E. Biazar, M. Jafarpour, M. Montazeri, A. Majdi, S. Aminifard, M. Zafari, H. R. Akbari and H. G. Rad, Int. J. Nanomed., 2011, 6, 1117.

7 S. Hussain, S. Boland, A. Baeza-Squiban, R. Hamel, L. C. Thomassen, J. A. Martens, M. A. Billon-Galland, J. Fleury-Feith, F. Moisan and J.-C. Pairon, Toxicology, 2009, 260, 142-149.

8 D. Chen, F. Huang, Y.-B. Cheng and R. A. Caruso, Adv. Mater., 2009, 21, 2206-2210.

9 A. Primo, A. Corma and H. García, Phys. Chem. Chem. Phys., 2011, 13, 886-910.

10 Y. Wen and H. Ding, Chin. J. Catal., 2011, 32, 36-45. 
11 K. Joshi and V. Shrivastava, Appl. Nanosci., 2011, 1, 147-155. 12 G. Federici, B. J. Shaw and R. D. Handy, Aquat. Toxicol., 2007, 84, 415-430.

13 S. B. Lovern and R. Klaper, Environ. Toxicol. Chem., 2006, 25, 1132-1137.

14 K. Hund-Rinke and M. Simon, Environ. Sci. Pollut. Res., 2006, 13, 225-232.

15 R. Dunford, A. Salinaro, L. Cai, N. Serpone, S. Horikoshi, H. Hidaka and J. Knowland, FEBS Lett., 1997, 418, 87-90.

16 S.-C. Kim and D.-K. Lee, Microchem. J., 2005, 80, 227-232.

17 N. B. Hartmann, F. Von der Kammer, T. Hofmann, M. Baalousha, S. Ottofuelling and A. Baun, Toxicology, 2010, 269, 190-197.

18 A. Hoshino, K. Fujioka, T. Oku, M. Suga, Y. F. Sasaki, T. Ohta, M. Yasuhara, K. Suzuki and K. Yamamoto, Nano Lett., 2004, 4, 2163-2169.

19 D. S. Gorman and R. Levine, Proc. Natl. Acad. Sci. U. S. A., 1965, 54, 1665.

20 S. Hutner, L. Provasoli, A. Schatz and C. Haskins, Proc. Am. Philos. Soc., 1950, 94, 152-170.
21 Cold Spring Harbor Protocols, 2010, 2010, pdb.rec12315, http://cshprotocols.cshlp.org/content/2010/9/pdb.rec12315.

22 S. Mahshid, M. S. Ghamsari, M. Askari, N. Afshar and S. Lahuti, Semicond. Phys., Quantum Electron. Optoelectron., 2006, 9, 65-68.

23 A. L. Patterson, Phys. Rev., 1939, 56, 978-982.

24 K. Hartmut, Analysis, ed. K. Peach and M. V. Tracey, 1983, vol. 4, pp. 142-196.

25 S. Mozia, in Polish Journal of Chemical Technology, 2008, p. 42.

26 L. K. Adams, D. Y. Lyon and P. J. Alvarez, Water Res., 2006, 40, 3527-3532.

27 K. Kasemets, A. Ivask, H.-C. Dubourguier and A. Kahru, Toxicol. In Vitro, 2009, 23, 1116-1122.

28 R. F. Fakhrullin, J. García-Alonso and V. N. Paunov, Soft Matter, 2010, 6, 391-397.

29 R. F. Fakhrullin, A. I. Zamaleeva, R. T. Minullina, S. A. Konnova and V. N. Paunov, Chem. Soc. Rev., 2012, 41, 4189-4206.

30 J. García-Alonso, R. F. Fakhrullin and V. N. Paunov, Biosens. Bioelectron., 2010, 25, 1816-1819. 